\title{
Pengaruh Product Innovation dan Brand Image Terhadap Keputusan Pembelian Smartphone Oppo Pada Konsumen Toko Jaya Ponsel Cabang Skip Kota Bengkulu.
}

\author{
Elprida Silalahi ${ }^{1}$ \\ ${ }^{1}$ Program Studi Manajemen UM. Bengkulu \\ Hasil Penelitian FEB UM. Bengkulu Tahun 2020
}

\begin{abstract}
ABSTRAK
Penelitian ini berjudul Pengaruh Product Innovation dan Brand Image Terhadap Keputusan Pembelian Smartphone Oppo Pada Konsumen Toko Jaya Ponsel Cabang Skip Kota Bengkulu. Rumusan masalah dalam penelitian ini yaitu apakah Product Innovation dan Brand Image berpengaruh signifikan terhadap Keputusan Pembelian Smartphone Oppo Pada Konsumen Toko Jaya Ponsel Cabang Skip Kota Bengkulu. Tujuan dari penelitian ini adalah Untuk mengetahui pengaruh Product Innovation dan Brand Image berpengaruh signifikan terhadap Keputusan Pembelian Smartphone Oppo Pada Konsumen Toko Jaya Ponsel Cabang Skip Kota Bengkulu.

Penelitian ini dilakukan pada Konsumen Smartphone Oppo pada Toko Jaya Ponsel Cabang Simpang Skip Kota Bengkulu. Sedangkan waktu penelitian ini dilakukan selama 14 hari yakni pada tanggal 26 januari sampai 8 Februari 2020. Adapun populasi dari penelitian ini adalah Konsumen smartphone oppo Toko Jaya Ponsel Cabang Skip Kota Bengkulu, sedangkan sempel penelitian ini adalah Konsumen smartphone oppo Toko Jaya Ponsel Cabang Skip Kota Bengkulu yang berjumlah 100 orang responden dan menggunakan metode kuantitatif.

Dengan teknik analisis data uji penelitian, hasil penelitian dapat disimpulkan bahwa persepsi responden tentang Product Innovation $\left(\mathrm{X}_{1}\right)$ Dan Brand Image $\left(\mathrm{X}_{2}\right)$ berpengaruh terhadap Keputusan Pembelian $(\mathrm{Y})$ dengan hasil regresi linier berganda didapat persamaan sebagai berikut : $\mathrm{Y}=4.891+0.633\left(\mathrm{X}_{1}\right)+0.507$ $\left(\mathrm{X}_{2}\right)$. Serta koefisien determinasi sebesar $\mathrm{R}^{2}=0.837$ atau $83.7 \%$ melalui uji hipotesis secara bersama-sama (simultan) dan sendiri-sendiri (parsial) dalam penelitian ini dengan menggunakan uji f dan uji t, Product Innovation $\left(\mathrm{X}_{1}\right)$ dan Brand Image $\left(\mathrm{X}_{2}\right)=0.000$, itu bearti nilai $\mathrm{f}_{\text {sig }}<0.05$ menunjukkan secara bersamasama dan yang pengaruh yang signifikan.
\end{abstract}

Kata kunci : Product Innovation, Brand Image dan Keputusan Pembelian 


\section{BAB I \\ PENDAHULUAN}

\subsection{Latar Belakang}

Diera digitalisasi telekomunikasi sekarang ini, konsumen dihadapkan dengan berbagai macam alat dan teknologi yang menawarkan kemudahan dengan berbagai fitur-fitur yang sangat canggih dan menarik. Teknologi komunikasi diera digitalisasi semakin mendapat tempat sebagai salah satu bisnis yang berkembang pesat dewasa ini, hal tersebut tentunya menjadi tantangan sekaligus mendorong seluruh perusahaan teknologi di dunia untuk menciptakan produk yang dapat memenuhi kebutuhan pasar. Tantangan ini juga didukung oleh keberadaan perusahaan sejenis yang menawarkan produk dan karakteristik yang hampir serupa seperti perusahaan smartphone oppo, Samsung, Xiomi, Vivo dan Realme.

Seiring berkembangnya teknologi dan informasi membuat konsumen lebih cerdas dalam memilih suatu produk. Salah satu faktor yang dipertimbangkan konsumen adalah inovasi produk. Inovasi produk dapat meningkatkan nilai tambah suatu produk, sehingga hal ini akan mempengaruhi konsumen dalam menentukan keputusan pembelian. Perubahan pasar seperti ini menuntut perusahaan untuk melakukan Product Innovation (inovasi produk) pada produk yang dimiliki agar dalam rangka mempertahankan kelangsungan hidup dan memperoleh keuntungan perusahaan (Tjiptono, 2008).

Pada perusahaan besar inovasi produk sudah menjadi strategi pasar yang berkelanjutan sesuai dengan kebutuhan pasar guna memepertahankan brand 
image (citra merk). Tetapi bagaimana dengan perusahaan Smartphone Oppo apakah strategi pemasaran melalui inovasi dapat mempengaruhi keputusan pembelian smartphone Oppo secara berkelanjutan. "Inovasi produk adalah suatu produk yang dianggap sebagai sesuatu yang baru oleh calon pengguna. Tidak menjadi masalah apakah produk tersebut tergolong baru terhadap dunia atau beberapa kategori lain yang termasuk dalam produk baru." (Lamb dan Hair, 2001:462)s.

Selain product innovation (inovasi produk), brand image (citra merek) juga merupakan hal yang dipertimbangkan konsumen ketika melakukan keputusan pembelian."Citra merek merupakan aspek yang sangat penting dari merek Smartphone. Citra merek adalah identitas (termasuk personalitas simbol, proposisi nilai, brand essence, dan posisi merek). Citra merek merupakan bagaimana konsumen mempersepsi merek secara aktual yang merupakan opini yang dibentuk konsumen sebagai interpretasi dari semua yang dilakukan perusahaan Aaker dan Robinette dalam Ismail (2012:62).

Menurut Kotler dan Armstrong (2008:282), para pemasar harus mampu dalam menempatkan merek dengan baik dalam pikiran para konsumennya. Mengembangkan citra merek yang kuat adalah salah satu cara untuk membuat konsumen mengenal produk tersebut. Hal tersebut akan mempengaruhi perilaku konsumen dalam menentukan pilihan. Dari berbagai merek ternama lainnya yang menjadi pesaing dalam produk. 
Dunia bisnis yang juga ikut berkembang pesat sesuai dengan perkembangan dan kecanggihan teknologi adalah perusahaan Smartphone. Dalam perkembangannya perusahaan Smartphone banyak mengeluarkan brand (merek) produk ternama. Perusahaan Smartphone yang ikut berkembang adalah perusahan Smartphone Oppo, yang juga merupakan salah satu dari beberapa perusahaan Smartphone yang turut merajai pasar konsumen.

Oppo Smartphone merupakan produk yang dapat digunakan di semua kalangan masyarakat. Dalam memperkenalkan produk mereka, perusahaan Smartphone Oppo menggunakan strategi pemasaran dengan mengajak artis tanah air dalam hal ini perusahaan Smartphone Oppo menggunakan Raisa, Chealse Island dan Isyana sebagai brand ambassador dari produk perusahaan oppo smartphone. Brand ambassador adalah wajah dari perusahaan yang mereka wakili. Brand ambassador yang diperkenalkan oleh perusahaan Smartphone Oppo merupakan salah satu strategi pasar yang dilakukan oleh perusahaan agar produk yang mereka perkenalkan dapat dengan mudah tertanam di benak konsumen sebagai identitas produk mereka.

“.. Mohammad Habib Sagala dalam penelitinya mengatakan bahwa terbukti dengan melakukan pemasaran menggunakan brand ambassador membuat produk Smartphone Oppo berhasil menduduki 10 besar Smartphone terlaris di Indonesia...” ( Mohammad Habib Sagala, 2019).

Keputusan pembelian adalah proses konsumen dalam memilih atau menentukan untuk membeli produk atau jasa. "Proses pengambilan keputusan 
untuk membeli dapat dibagi menjadi lima tahap, yaitu mengenali kebutuhan, mencari informasi, mengevaluasi alternatif, mengambil keputusan, evaluasi pasca pembelian."(Suryani, 2012:17).dengan adanya brand image dan product innovation yang baik diharapkan mampu meningkatkan kepercayaan konsumen dalam mengambil keputusan untuk membeli produk oppo. Berikut ini adalah data penjualan smartphone oppo diseluruh Indonesia pada Q2 selama 3 tahun terakhir menurut Indonesia Top smartphone companiesby (YOY) :

Tabel 1.1

Indonesia Top smartphone companiesby (YOY) market share comporation

\begin{tabular}{|c|c|c|c|c|}
\hline \multirow[b]{2}{*}{ No. } & \multirow[b]{2}{*}{ Company } & Q 2' 2019 & Q 2' 2018 & Q 2' 2017 \\
\hline & & $\begin{array}{l}\text { Volume } \\
\text { Penjualan }\end{array}$ & $\begin{array}{l}\text { Volume } \\
\text { Penjualan }\end{array}$ & $\begin{array}{l}\text { Volume } \\
\text { Penjualan }\end{array}$ \\
\hline 1 & Samsung & $24 \%$ & $28 \%$ & $32 \%$ \\
\hline 2 & Vivo & $15 \%$ & $6 \%$ & $3 \%$ \\
\hline 3 & Xiomi & $19 \%$ & $19 \%$ & $3 \%$ \\
\hline 4 & Oppo & $26 \%$ & $17 \%$ & $24 \%$ \\
\hline 5 & Realme & $7 \%$ & & \\
\hline & Others & $9 \%$ & $30 \%$ & $38 \%$ \\
\hline & Total & $100 \%$ & $100 \%$ & $100 \%$ \\
\hline
\end{tabular}

Sumber : Tribun techno diakses pada 11 November pukul 11.30 WIB

Pada tabel 1.1 tersebut terlihat informasi terbaru dari lembaga riset pasar gartner yang menunujukan penjualan dari berbagai merk smartphone yang sejenis seperti Samsung, Vivo, Xiomi dan Realme. Adapun smartphone yang paling banyak diminati produksi Korea Selatan yaitu Samsung. Sedangkan Oppo khususnya terlihat dari kuartal 2 (Q2) tiga tahun terakhir (tahun 2017 2019) masih berada dibawah Samsung. Data ditersebut menunjukan bahwa 
penjualan Smartphone Oppo pada Q2 tahun 2017 terjual sebanyak 24\%, diketahui berikutnya yaitu tahun 2018 terjadi penurunan volume penjualan yaitu sebanyak 17\%, dan pada Q2 tahun berikutnya penjualan meningkat sebanyak $26 \%$ dibandingkan tahun sebelumnya. terjadi sebelumnya telah terjadi kenaikan dan penjualan pada penurunan produk Smartphone Oppo di Indonesia.

Toko Jaya Ponsel merupakan salah satu toko yang menjual produk smartphone oppo. Untuk mengetahui gambaran tingkat penjualan pada Toko Jaya Ponsel cabang Simpang SKIP Kota Bengkulu, berdasarkan hasil observasi peneliti dengan salah satu karyawan marketing Toko Jaya Ponsel pada tanggal 16 November 2019 tepatnya pada pukul 10.29 WIB memperoleh beberapa data diantaranya adalah hasil penjualan smartphone oppo pada tiga bulan terakhir yaitu Agustus - Oktober 2019 di Toko Jaya Ponsel cabang SKIP Kota Bengkulu.

Tabel 1.2

Target dan Pencapaian Bagian Penjualan Smartphone Oppo pada bulan Agustus - Oktober tahun 2019

\begin{tabular}{|l|l|l|l|l|}
\hline No & Bulan & Target & $\begin{array}{l}\text { Pencapaian } \\
\text { Penjualan }\end{array}$ & Keterangan \\
\hline 1. & Agustus & 450 unit & 432 Unit & Tidak Tercapai \\
\hline 2. & September & 401 Unit & 322 Unit & Tidak Tercapai \\
\hline 3. & Oktober & 400 Unit & 347 Unit & Tidak Tercapai \\
\hline & Total & 1251 Unit & 1101 Unit & Tidak Tercapai \\
\hline
\end{tabular}

Sumber : Toko Jaya Ponsel Simpang SKIP Kota Bengkulu, 16 November 2019 
Berdasarkan tabel 1.2 diatas dapat disimpulkan bahwa Toko Jaya Ponsel memiliki target yang telah ditetapkan, oleh Owner Toko Jaya Ponsel Cabang Simpang SKIP Kota Bengkulu. Adapun target penjualan yang sudah ditentukan selama tiga bulan terakhir Agustus - Oktober, terlihat setiap bulannya sebanyak 450 unit dibulan agustus, 401 unit dibulan september dan 400 unit dibulan oktober. Namun dapat kita lihat pada tabel diatas bahwa penjualan yang dicapai dari produk Oppo khususnya selama tiga bulan terakhir ini (agustus - oktober) tidak mencapai target.

Pemasaran yang dilakukan perusahaan membuat para pelaku usaha yang menjual brand produk mereka juga melakukan strategi pemasaran yang menarik. Pemasaran yang ditawarkan oleh setiap pelaku usaha yang menjual produk Smartphone Oppo bervariasi, hal ini karena setiap para pelaku usaha memiliki sistem perencanaan dan operasional yang berbeda. Pemasaran yang baik tidak hanya membantu pelaku usaha dalam memperkenalkan brand produk mereka dengan mudah, tetapi juga membantu kinerja penjualan. Pada Toko Jaya Ponsel sendiri dalam memasarkan produk Oppo Smartphone mereka melakukan strategi pemasaran dengan cara memberikan berbagai macam promosi yang telah disiapkan oleh pihak management toko Jaya Ponsel dan memberikan berbagai hal yang menarik apabila membeli produk handphone di Toko mereka. Dengan penaksiran pengaruh product innovation dan brand image diharapkan dapat mengetahui pengaruhnya terhadap keputusan pembelian smartphone oppo pada konsumen di Toko Jaya Ponsel Cabang Simpang SKIP Kota Bengkulu. 
Berdasarkan pemaparan latar belakang tersebut, penulis tertarik untuk melakukan penelitian yang berjudul "Pengaruh Product Innovation Dan Brand Image Terhadap Keputusan Pembelian Produk Smartphone OPPO Pada Konsumen Toko Jaya Ponsel Cabang SKIP Kota Bengkulu".

\subsection{Identifikasi Masalah}

Berdasarkan latar belakang yang telah diuraikan diatas maka identifikasi permasalahan yang akan dijadikan bahan penelitian adalah :

1. Product Innovation pada produk Smartphone $O P P O$ masih kurang menarik minat konsumen dikarenakn banyaknya persaingan antar perusahaan smartphone

2. Brand Image pada produk Smartphone OPPO masih rendah hal tersebut dapat dilihat target penjualan yang belum tercapai pada Toko Jaya Ponsel Cabang SKIP Kota Bengkulu

\subsection{Batasan Masalah}

Ruang lingkup yang ada pada penelitian ini dipusatkan dengan membatasi masalah yang meliputi strategi pemasaran melalui Product Innovation dan Brand Image, serta Keputusan Pembelian Produk Smartphone Oppo yang terdapat pada konsumen di Toko Jaya Ponsel Cabang SKIP Kota Bengkulu.

\subsection{Rumusan Masalah}

Berdasarkan latar belakang yang telah dipaparkan di atas, maka permasalahan yang akan dibahas di dalam penelitian ini adalah : 
1. Apakah Product Innovation berpengaruh terhadap keputusan pembelian Produk Smartphone Oppo pada konsumen di Toko Jaya Ponsel Cabang SKIP Kota Bengkulu?

2. Apakah Brand Image berpengaruh terhadap keputusan pembelian Produk Smartphone Oppo pada konsumen di Toko Jaya Ponsel Cabang SKIP Kota Bengkulu ?

3. Seberapa besar pengaruh Product Innovation dan Brand Image terhadap keputusan pembelian produk Smartphone Oppo pada konsumen di Toko Jaya Ponsel Cabang SKIP Bengkulu?

\subsection{Tujuan Penelitian}

Adapun tujuan dari penelitian skripsi ini adalah sebagai berikut :

\subsubsection{Tujuan Umum}

Tujuan penelitian ini adalah untuk mengetahui pengaruh Product Innovation dan Brand Image terhadap Keputusan Pembelian Produk Smartphone Oppo pada konsumen di Toko Jaya Ponsel Cabang SKIP Kota Bengkulu.

\subsubsection{Tujuan Khusus}

1. Untuk mengetahui pengaruh product innovation terhadap keputusan pembelian Smartphone Oppo pada konsumen Toko Jaya Ponsel Cabang SKIP Kota Bengkulu. 
2. Untuk mengetahui pengaruh brand image terhadap Keputusan Pembelian Smartphone Oppo di Toko Jaya Ponsel cabang SKIP Kota Bengkulu.

3. Untuk mengetahui pengaruh Product Innovation dan Brand Image terhadap keputusan pembelian Smartphone Oppo pada konsumen di Toko Jaya Ponsel Cabang SKIP Kota Bengkulu.

\subsection{Manfaat Penelitian}

Adapun manfaat penelitian diharapkan setelah penelitian ini berlangsung adalah dapat mengetahui strategi penerapan Product Innovation dan Brand Image terhadap Keputusan Pembelian produk Smartphone Oppo Pada Konsumen Toko Jaya Ponsel, antara lain :

1. Kegunaan Teorotis

Pengetahuan ini diharapkan dapat menjadi sumber pengetahuan, rujukan serta acuan bagi semua pihak yang ingin mengetahui pengaruh product innovation dan brand image terhadap keputusan pembelian. Dan juga sebagai pertimbangan bagi perusahaan agar dijadikan bahan acuan dan referensi bagi penelitian sejenis yang dilakukan dimasa yang akan datang.

2. Kegunaan Praktis

Dar hasil penelitian ini diharapkan mampu memberikan pemahaman akan pengaruh product innovation dan brand image terhadap keputusan pembelian dan juga diharapkan dapat dijadikan acuan bagi Toko Jaya Ponsel dalam meningkatkan strategi penerapan Product Innovation dan Brand Image terhadap Keputusan Pembelian. 


\section{BAB II \\ STUDI PUSTAKA}

\subsection{Deskripsi Konseptual}

\subsubsection{Keputusan Pembelian}

Keputusan pembelian merupakan pemikiran dimana individu mengevaluasi berbagai pilihan dan memutuskan pilihan pada suatu produk dari sekian banyak pilihan. Proses keputusan pembelian dilihat sebagai kegiatan yang terdiri dari seleksi, memperoleh dan mengevaluasi (Rossiter, 2003). Rangsangan pemasaran dan lingkungan memasuki karakteristik konsumen dan proses keputusan pembelian Kotler et al., (1999). Melalui konsumsi dan nilai produk untuk konsumen yang mencerminkan pengaruh sosial dan lingkungan dapat mempengaruhi kebutuhan untuk kepatuhan dan menciptakan perilaku pembelian (Kim et al., 2002). Berikut definisi keputusan pemebelian menurut para ahli :

1. Menurut Kotler \& Amstrong (2014), keputusan pembelian adalah tahap dalam proses pengambilan keputusan pembeli di mana konsumen benarbenar membeli.

2. Menurut Schiffman dan Kanuk (2014) keputusan pembelian didefinisikan sebagai sebuah pilihan dari dua tahu lebih alternatif pilihan.

3. Menurut Tjiptono (2012) keputusan pembelian adalah sebuah proses dimana konsumen mengenal masalahnya, mencari informasi mengenai produk atau merek tertentu dan mengevaluasi secara baik masing-masing 
alternatif tersebut dapat memecahkan masalahnya, yang kemudian mengarah kepada keputusan pembelian.

4. Menurut Suharno (2010:96) keputusan pembelian adalah tahap dimana pembeli telah menentukan pilihan dan melakukan pembelian produk atau jasa, serta mengkonsumsinya.

Dari pengertian tersebut dapat disimpulkan keputusan pembelian merupakan sebuah tahap dimana pembeli telah menentukan pilihan untuk pengambilan keputusan yang diawali dengan pengenalan masalah kemudian mengevaluasinya dan memutuskan produk yang paling sesuai dengan kebutuhan.

\subsubsection{Faktor-Faktor yang mepengaruhi Keputusan Pembelian Konsumen}

Kotler (2005) menyatakan bahwa perilaku pembelian konsumen dipengaruhi oleh faktor- faktor berikut :

1. Faktor budaya

Faktor-faktor budaya mempunyai pengaruh yang paling luas dan paling dalam. Budaya, sub-budaya dan kelas sosial sangat penting bagi perilaku pembelian. Budaya merupakan penentu keinginan dan perilaku yang paling dasar. Sub budaya mencakup kebangsaan, agama, kelompok, ras, dan wilayah geografis. Sedangkan kelas sosial adalah pembagian masyarakat yang relatif homogen dan permanen, yang tersusun secara hirarkis dan yang para anggotanya menganut nilai, minat, dan perilaku yang serupa. Kelas sosial tidak hanya mencerminkan penghasilan, tetapi 
juga indikator lain seperti pekerjaan, pendidikan, dan wilayah tempat tinggal.

\section{Faktor social}

Selain faktor budaya, perilaku konsumen dipengaruhi oleh faktorfaktor sosial seperti kelompok acuan, keluarga, serta peran dan status sosial masyarakat.

3. Faktor pribadi

Keputusan pembeli juga dipengaruhi oleh karakteristik pribadi. Karakteristik tersebut meliputi usia dan tahap siklus hidup, pekerjaan, keadaan ekonomi, gaya hidup, serta kepribadian dan konsep diri pembeli.

4. Faktor psikologis

Pilihan pembelian seseorang dipengaruhi oleh empat faktor psikologi utama. Faktor-faktor tersebut terdiri dari motivasi, persepsi, pembelajaran, serta keyakinan dan sikap. Kebutuhan akan menjadi motif jika ia didorong hingga mencapai tahap intensitas yang memadai. Motif adalah kebutuhan yang memadai untuk mendorong seseorang bertindak. Persepsi adalah proses yang digunakan oleh individu untuk memilih, mengorganisasi, dan menginterpretasi masukan informasi guna menciptakan gambaran dunia yang memiliki arti. Persepsi dapat sangat beragam antara individu satu dengan yang lain yang mengalami realitas yang sama. 


\subsubsection{Tahap-Tahap Proses Pengambilan Keputusan Pembelian}

Menurut Kotler dan Amstrong (2012) konsumen akan melalui lima tahap dalam pengambilan keputusan pembelian. Gambaran proses keputusan pembelian, sebagai berikut:

1. Pengenalan kebutuhan Merupakan tahap pertama proses keputusan pembeli, dimana konsumen menyadari suatu masalah atau kebutuhan.

2. Pencarian informasi Merupakan tahap proses keputusan pembeli dimana konsumen ingin mencari informasi lebih banyak; konsumen mungkin hanya memperbesar perhatian atau melakukan pencarian informasi secara aktif.

3. Evaluasi alternatif Merupakan tahap proses keputusan pembeli dimana konsumen menggunakan informasi untuk mengevaluasi merek alternatif dalam sekelompok pilihan.

4. Keputusan pembelian Merupakan keputusan pembeli tentang merek mana yang paling disukai, tetapi dua faktor bisa berada antara niat pembelian dan keputusan pembelian.

5. Perilaku pasca pembelian Merupakan tahap proses keputusan pembeli dimana konsumen mengambil tindakan selanjutnya setelah pembelian, berdasarkan kepuasan atau ketidakpuasan mereka. 


\subsubsection{Indikator Keputusan Pembelian}

Menurut Kotler (2009), indikator - indikator dalam keputusan pembelian adalah :

1. Kemantapan pada sebuah produk merupakan keputusan yang dilakukan konsumen setelah mempertimbangkan berbagai informasi yang mendukung pengambilan keputusan.

2. Kebiasaan dalam memberi produk, merupakan pengalaman orang terdekat (orang tua, saudara) dalam menggunakan suatu produk.

3. Memberikan rekomendasi kepada orang lain, merupakan penyampaian informasi yang positif kepada orang lain, agar tertarik untuk melakukan pembelian.

4. Melakukan pembelian ulang, merupakan pembelian yang berkesinambungan, setelah konsumen merasakan kenyamanan atas produk atau jasa yang diterima.

\subsubsection{Product Innovation ( Inovasi Produk )}

Berikut beberapa definisi product innovation (inovasi produk) menurut beberapa ahli :

1. Menurut Hurley and Hult (1998: 45) mendefinisikan inovasi produk sebagai sebuah mekanisme perusahaan untuk beradaptasi dalam lingkungan yang dinamis, oleh karena itu perusahaan dituntut untuk mampu menciptakan pemikiran- pemikiran baru, gagasan-gagasan baru, 
dan menawarkan produk yang inovatif serta peningkatan pelayanan yang memuaskan pelanggan.

2. Menurut Crawford dan De Benedetto (2000:9), inovasi produk adalah Inovasi yang digunakan dalam keseluruhan operasi perusahaan dimana sebuah produk baru diciptakan dan dipasarkan, termasuk inovasi di segala proses fungsional atau kegunaannya.

3. Menurut Dourgerty (2004:16) "inovasi produk merupakan suatu cara yang penting bagi perusahaan agar tetap dapat beradaptasi dengan pasar, teknologi, serta persaingan".

4. Menurut Drucker dalam Berthon, et al. (2005:16) menyatakan bahwa inovasi produk merupakan satu hal yang potensial untuk menciptakan pemikiran dan imajinasi orang yang pada akhirnya menciptakan pelanggan.

5. Menurut Nelly, et al. (2008:16) berpendapat bahwa inovasi produk menunjukkan pada pengembangan produk dan pengenalan produk baru yang di kembangkan dan berhasil dipasaran, inovasi produk dapat berupa perubahan desain, komponen dan arsitektur produk.

Dari pemaparan pendapat para ahli di atas dapat ditarik kesimpulan mengenai definisi product innovation (inovasi produk) adalah rangkaian dari berbagai proses fungsional yang saling mempengaruhi antara yang satu dengan yang lain, untuk beradaptasi dalam lingkungan yang dinamis. Oleh karena itu perusahaan dituntut untuk mampu menciptakan pemikiran- pemikiran baru, gagasangagasan baru. Inovasi produk juga dapat berupa perubahan desain, komponen dan arsitektur produk, dalam menawarkan produk yang inovatif serta 
peningkatan pelayanan yang menciptakan dan memuaskan pelanggan dalam mencapai keberhasilan.

\subsubsection{Strategi Membangun Product Innovation (Inovasi Produk)}

Berikut adalah cara membangun produk yang inovatif menurut para ahli yaitu sebagai berikut :

1. Menurut Kotler (1987), cara yang dapat ditempuh untuk membangun produk yang inovatif yaitu dengan :

a. Mengembangkan atribut produk yang baru

b. Mengembangkan beragam tingkat mutu

c. Mengembangkan model dan ukuran produk.

2. Menurut Gatgnon dan Xuereb (1997:79), menyatakan bahwa dalam inovasi produk terdapat tiga inovasi yang dapat dilakukan yaitu melalui :
a. Keunggulan produk
b. Kesamaan produk
c. Biaya produk.

3. Menurut Martensen dan Dahlgaard (1998:878), keberhasilan suatu inovasi produk dalam perusahaan bisa di capai apabila perusahaan dapat dengan cepat bereaksi dengan kondisi pasar baru dan kebutuhan pelanggan. Selain itu perusahaan dapat secara berkesinambungan mencari solusi yang kreatif serta peningkatan secara terus-menerus dalam manghasilkan produk. Perusahaan juga harus bisa beradaptasi serta berinovasi secara terus menerus. 
Dari uraian pendapat para ahli diatas disimpulkan bahwa cara dalam membangun produk yang inovatif melalui beberapa tahapan pengembangan yaitu: atribut produk yang baru, beragam tingkat mutu, model dan ukuran produk. Serta dapat pula dilakukan dengan memperhatikan Keunggulan produk, Kesamaan produk, Biaya produk. Perusahaan juga dituntut untuk mampu berinovasi secara berkesinambungan mencari solusi yang kreatif serta peningkatan secara terus-menerus dalam manghasilkan sebuah produk.

\subsubsection{Indikator Product Innovation (Inovasi Produk)}

Menurut Kotler ( 2007:37) menjelaskan adanya enam indikator dari inovasi produk, yaitu:

1. Perluasan lini (line extensions) yaitu produk yang dihasilkan perusahaan tidaklah benar-benar baru tetapi relatif baru untuk sebuah pasar.

2. Produk baru (me too - product) yaitu produk baru bagi perusahaan tetapi tidak baru bagi pasar.

3. Produk benar-benar baru (new - to - the - world - product) adalah produk yang termasuk baru baik bagi perusahaan maupun pasar.

Berdasarkan dari pemaparan diatas dapat di tarik kimpulkan bahwa indikator dari inovasi produk adalah serangkaian proses untuk menghasilkan sebuah produk yang belum pernah ada atau relatif baru bagi pasar atau perusahaan itu sendiri. 
Terdapat 7 golongan inovasi produk antara lain (Kotler, 2007:37) :

1. Produk baru bagi dunia, Produk baru bagi dunia merupakan suatu produk baru yang menciptakan pasar yang sama sekali baru, dimana produk sejenis belum pernah dibuat oleh pihak lain sehingga produk tersebut merupakan produk yang benar- benar baru sehingga dapat membedakan produk baru tersebut dengan produk-produk sejenis yang lainnya.

2. Lini produk baru, Lini produk baru merupakan produk baru yang memungkinkan perusahaan memasuki pasar yang telah mapan untuk pertama kalinya memasuki pasar yang sudah ada, dengan lini produk baru dapat mempengaruhi konsumen untuk menentukan pilihan produk

3. Tambahan pada lini produk yang telah ada, tambahan pada lini produk yang telah ada merupakan produk-produk baru yang melengkapi atau menambah suatu lini produk perusahaan yang telah mantap sehingga produk menjadi lebih beragam sehingga memunculkan banyak pilihan.

4. Perbaikan dan revisi produk yang telah ada, perbaikan dan revisi produk yang telah ada merupakan produk yang memberikan kinerja yang lebih baik atau nilai yang dianggap lebih hebat dan menggantikan produk yang telah ada, dimana dihasilkan produk baru dengan daya kerja/kegunaan yang disempurnakan.

5. Penentuan kembali, penentuan kembali merupakan produk yang sudah ada diarahkan atau dipasarkan ke pasar atau segmen pasar yang baru, hasil ini diharapkan dapat memperluas pemasaran dengan memperoleh 
pangsa pasar atau konsumen baru sebagai upaya untuk meningkatkan penjualan.

6. Pengurangan biaya, pengurangan biaya merupakan produk baru yang menyediakan produk yang daya kerja/kegunaanya serupa dengan harga yang lebih murah atau rendah, hal ini dimaksudkan mempengaruhi keputusan konsumen untuk membeli suatu produk dan hal ini berdampak pada meningkatnya volume penjualan suatu produk.

7. Adanya kesamaan tampilan produk sejenis dari pesaing merupakan faktor pendorong terjadinya inovasi produk, umumnya produk pesaing itu muncul tanpa mengalami perubahan yang berarti bahkan cenderung statis. Keadaan seperti ini dapat menjadi hal menguntungkan, karena persaingan yang timbul dengan munculnya produk pesaing dapat diatasi dengan melakukan inovasi produk.

Kesimpulannya Inovasi produk merupakan sesuatu yang dapat dilihat sebagai kemajuan fungsional produk yang dapat membawa produk selangkah lebih maju dibandingkan dengan produk pesaing. Apabila produk tersebut memiliki suatu kelebihan yang dipandang sebagai nilai tambah bagi konsumen. Pengembangan produk baru memerlukan upaya, waktu dan kemampuan termasuk besarnya risiko dan biaya kegagalan.

\subsubsection{Brand Image (Citra Merek)}

Citra merek adalah yang membentuk dasar kesuksesan merek (Keller, 1993). Dalam citra merek yang dikonseptualisasikan dalam hal asosiasi merek, skenario 
bisnis merek, citra merek membentuk dasar untuk membuatlebih kinerja yang baik, citra merek, penilaian konsumen, dan keputusan pemasaran strategis konsumen tentang penargetan pasar tertentu yang perasaan dibentuk dalam benak pelanggan. Berikut ini terdapat beberapa definisi brand menurut para ahli yaitu diantaranya :

1. Citra merek adalah salah satu elemen kunci ekuitas merek dalam manajemen merek yang sukses (Aaker, 1991).

2. Menurut Kotler dan Keller (2009 : 332), Brand merupakan nama, istilah, tanda, simbol, atau rancangan, atau kombinasi dari semuanya, yang dimaksudkan untuk mengidentifikasikan barang atau jasa atau kelompok penjual dan untuk mendiferensiasikannya (membedakan) dari barang atau jasa pesaing. Citra merek adalah yang membentuk dasar kesuksesan merek (Keller, 1993). Ini mengacu pada salah satu aset utama ekuitas merek yang membentuk keseluruhan kumpulan asosiasi yang terkait dengan merek yang dikembangkan dalam evaluasi pelanggan terhadap pelanggan terhadap suatu merek (Keller, 1993).

3. Menurut Kartajaya (2010 : 62), mendefinisikan brand sebagai: "Aset yang menciptakan nilai bagi pelanggan dengan meningkatkan kepuasan dan menghargai kualitas.

4. Menurut Kotler dan Gary Armstrong (2007 : 80), dimana "Brand Image” adalah himpunan keyakinan konsumen mengenai berbagai merek.

5. Menurut Fandy Tjiptono (2011 : 12), brand image adalah deskrispi 
tentang asosiasi dan keyakinan konsumen terhadap merek tertentu.

6. Menurut Rangkuti (2008:3), brand image adalah "Sekumpulan asosiasi merek yang terbentuk dan melekat di benak konsumen.

7. Menurut Sangadji dan Sopiah (2013:237), brand image merupakan asosiasi yang bersifat positif atau negatif tergantung pada persepsi seseorang terhadap suatu brand.

Dari berbagai pendapat, diatas dapat disimpulkan bahwa brand Image (citra merek) merupakan suatu bentuk asosiasi yang bersifat positif atau negatif tergantung pada persepsi seseorang terhadap suatu brand. Atau diartikan juga suatu identitas merk baik berupa nama, istilah, tanda, lambang, desain atau kombinasi dari semuanya untuk mengidentifikasikan suatu produk atau jasa dari suatu kelompok penjual untuk membedakan produknya dari yang lain. Dengan tujuan dapat menciptakan nilai bagi pelanggan dan meningkatkan kepuasan serta menghargai kualitas suatu produk maupun jasa yang melekat di benak konsumen. Serta dapat menjadi kekuatan untuk menghambat kegiatan pemasaran pesaing.

\subsubsection{Faktor-Faktor Pendukung Terbentuknya Brand Image}

Menurut Keller (dalam Ferrinadewi, 2009), faktor-faktor pendukung terbentuknya brand image dapat dijelaskan sebagai berikut :

1. Keunggulan asosiasi merek (favor-ability of brand association). Hal ini dapat membuat konsumen percaya bahwa atribut dan manfaat yang di- berikan oleh suatu brand dapat memuaskan kebutuhan dan keinginan 
konsumen sehingga menciptakan sikap yang positif terhadap brand tersebut.

2. Kekuatan asosiasi merek (strenght of brand association). Hal ini bergantung pada bagaimana informasi masuk dalam ingatan konsumen dan bagaimana informasi tersebut dikelola oleh data sensoris di otak sebagai bagian dari brand image. Ketika konsumen secara aktif memikirkan dan menguraikan arti informasi pada suatu produk atau jasa, akans tercipta asosiasi yang semakin kuat pada ingatan konsumen.

3. Keunikan asosiasi merek (uniqueness of brand association). Sebuah brand haruslah unik dan menarik sehingga produk tersebut memiliki ciri khas dan sulit untuk ditiru para pesaing. Keunikan suatu produk akan mem- berikan kesan yang cukup membekas terhadap ingatan pelanggan akan keunikan brand. Sebuah brand yang memiliki ciri khas haruslah dapat melahirkan keinginan pelanggan untuk mengetahui lebih jauh dimensi brand yang terkandung di dalamnya.

4. Menurut Oliver (dalam Hurriyati, 2010), loyalitas adalah komitmen pelanggan bertahan secara mendalam untuk berlangganan kembali atau melakukan pembelian ulang produk atau jasa terpilih secara konsisten pada masa yang akan datang, meskipun pengaruh situasi dan usaha-usaha pemasaran berpotensi menyebabkan perubahan perilaku.

\subsubsection{Strategi membangun Brand Image}

Suatu merek harus memiliki strategi yang baik dan kuat dalam membangun merek dengan mengenalkan dan memasarkan produk sesuai 
dengan nilai jual merek yang telah ditentukan oleh produsen. Hal ini berguna untuk membangun citra merek (brand image) dan kepercayaan di mata konsumen terhadap produk yang dipasarkan.

Menurut (Rangkuti 2008 :38) terdapat beberapa strategi membangun brand image, sebagai berikut:

1. Merek Baru (New brand)

Perusahaan dapat menciptakan nama atau merek baru ketika ingin memasarkan produk baru. Hal ini dikarenakan nama atau merek sebelumnya tidak sesuai dengan konsep produk baru yang akan ditawarkan di pasar.

2. Multi Merek (Multi Brand)

Perusahaan mengelola berbagai nama merek tambahan dalam kategori produk yang sama. Hal tersebut untuk memberikan fungsi dan manfaat yang sesuai dengan motif pembelian konsumen terhadap produk.

3. Perluasan Merek (Brand Extension)

Menggunakan nama atau merek sebelumnya yang telah berhasil untuk meluncurkan produk baru.

4. Perluasan Lini (Lini Extension)

Strategi perluasan lini dilakukan dengan cara memperkenalkan berbagai macam atribut tambahan atau variasi terhadap kategori produk yang sudah ada dengan nama atau merek yang sama, seperti: rasa, bentuk, warna, atau ukuran kemasan yang baru. 


\subsubsection{Indikator Brand Image (Citra Merek)}

Indikator - indikator yang mebentuk citra merek menurut Biel dalam jurnal penelitian Sulistiyaningsih (Evawati, 2012). Adapun indikator - indikator yang membentuk citra merek yang dimaksud ialah :

\section{Citra Korporat}

Citra yang ada didalam perusahaan itu sendiri, perusahaan sebagai organisasi berusaha membangun citranya dengan tujuan agar perusahaan terlihat bagus, sehingga nantinya akan mempengaruhi apa yang dilakukan oleh perusahaan tersebut.

\section{Citra Produk}

Citra konsumen terhadap suatu produk yang dapat berdampak positif maupun negatif yang berkaitan dengan kebutuhan, keinginan dan harapan konsumen. Citra dari produk dapat mendukung terciptanya sebuah citra dari merek tersebut.

\section{Citra Pemakai}

Dapat dibentuk langsung dari pengalaman dan kontak dengan pengguna merek tersebut. Manfaat adalah nilai pribadi konsumen yang diletakan terhadap atribut dari produk atau layanan yaitu apa yang konsumen pikir akan merek yang didapatkan dari produk atau layanan tersebut.

Dari penjelasan diatas dapat disimpulkan bahwa indikator-indikator brand image (citra merek) diantaranya yaitu merupakan citra yang ada didalam perusahaan baik pelayanan dari perusahaan itu sendiri maupun produknya yang 
akan berdampak pada persepsi konsumen baik yang bersifat positif maupun negatif yang berkaitan dengan kebutuhan, keinginan dan harapan konsumen.

\subsubsection{Pengaruh Product Innovation Terhadap Keputusan Pembelian}

Inovasi dalam pengambangan produk atau pengembangan pasar dilakukan dalam kaitannya untuk meningkatkan daya saing. Inovasi merupakan usaha penjabaran ide kedalam aktivitas bisnis baik secara radikal ataupun secara bertahap. Namun dimanapun inovasi dilakukan, sasaran utamanya ialah bagi konsumennya." (Kosasih, 2009:66). Jadi, ketika inovasi pada produk mampu memenuhi harapan konsumen, maka peluang untuk melakukan keputusan pembelian akan menjadi lebih besar.

Persepsi konsumen tentang citra merek merupakan salah satu faktor dalam menentukan keputusan pembelian. Konsumen akan lebih memilih produk yang menurut persepsinya memiliki citra yang bagus. Hal tersebut didukung oleh teori dari Ferrinadewi (2008:168), Pemasar harus mengupayakan agar tercipta presepsi bahwa merek yang mereka tawarkan sesuai dengan nilai-nilai yang diyakini oleh konsumen dalam keputusan pembeliannya melalui strategi komuniksai dalam iklan yang dipakai atau alat komunikasi lainnya, pemasar harus menekankan pada nilai konsumen yang mereka utamakan sehingga tercipta asosiasi yang dekat.

\subsubsection{Pengaruh Brand Image (Citra Merek) Terhadap Keputusan Pembelian}

Menurut Ferinda Dewi (2009: 203) menyatakan bahwa brand image (citra merek) merupakan konsep yang diciptakan oleh konsumen karena alasan subjektif 
dan emosional pribadinya. Ditambahkan citra merek adalah persepsi tentang merek yang digambarkan oleh asosiasi merek yang ada didalam ingatan konsumen. Citra merek yang baik terhadap suatu barang akan menigkatkan persepsi yang baik pula terhadap keputusan pembelian suatu produk.

Wicaksono (2007: 56), mengemukakan pentingnya pengembangan citra merek dalam keputusan pembelian. Brand Image yang dikelola dengan baik akan menghasilkan konsekuensi yang positif, meliputi :

1. Meningkatkan pemahaman terhadap aspek- aspek perilaku konsumen dalam mengambil keputusan.

2. Memperkaya orientasi konsumsi terhadap hal-hal yang bersifat simbolis lebih dari fungsi-fungsi produk.

3. Meningkatkan kepercayaan konsumen terhadap produk.

4. Meningkatkan keunggulan berasaing berkelanjutan, mengingat inovasi teknologi sangat mudah ditiru oleh pesaing.

Menciptakan kesan menjadi salah satu karakteristik dasar dalam orientasi pemasaran modern yaitu lewat pemberian perhatian yang lebih serta penciptaan merek yang kuat. Implikasi dari hal tersebut menciptakan brand image suatu produk itu sendiri dibenak konsumen dan menjadikan motivasi dasar bagi konsumen dalam memilih suatu produk. 


\subsection{Hasil Penelitian yang Relevan}

Tabel 2.1

Hasil Penelitian yang Relevan

\begin{tabular}{|c|c|c|c|c|}
\hline $\begin{array}{c}\text { Nama } \\
\text { peneliti }\end{array}$ & Judul & $\begin{array}{l}\text { Variabel } \\
\text { penelitian }\end{array}$ & $\begin{array}{l}\text { Metode } \\
\text { penelitian }\end{array}$ & $\begin{array}{l}\text { Hasil } \\
\text { penelitian }\end{array}$ \\
\hline $\begin{array}{l}\text { Tambunan } \\
\text { Ellisabet, } \\
\text { Marupa } \\
\text { Siregar } \\
\text { (E-ISSN) } \\
\text { Vol.3 No.1 } \\
(2018)\end{array}$ & $\begin{array}{l}\text { Pengaruh } \\
\text { Promosi dan } \\
\text { Inovasi } \\
\text { produk } \\
\text { terhadap } \\
\text { Keputusan } \\
\text { pembelian } \\
\text { Batik } \\
\text { Azzahra } \\
\text { Medan }\end{array}$ & $\begin{array}{l}\text { Variabel } \\
\text { (X1) sebagai } \\
\text { promosi dan } \\
\text { Variabel } \\
\text { (X2) sebagai } \\
\text { Inovasi } \\
\text { Produk } \\
\text { sedangkan } \\
\text { keputusan } \\
\text { pembelian } \\
\text { sebagai } \\
\text { variabel (Y) }\end{array}$ & $\begin{array}{l}\text { Kuantitatif, } \\
\text { analisis } \\
\text { regresi } \\
\text { sederhana }\end{array}$ & $\begin{array}{l}\text { Berdasarkan uji F } \\
\text { ttau uji simultan } \\
\text { bada tabel } 4.17 \\
\text { dapat dilihat bahwa } \\
\text { hilai pada } \mathrm{F} \\
\text { hitungsebesar } 10,302 \text {, } \\
\text { dengan tingkat } \\
\text { pignifikan } 0,000 \\
\text { sedangkan nilai pada } \\
\text { F tabel pada } \alpha=5 \% \\
\text { dalah 1,984. Maka } \\
\text { dapat disimpulkan } \\
\text { fhitung (10,302) } \\
\text { l. f tabel ( } 1,984) \\
\text { dan tingkat } \\
\text { signifikannya } \\
0,000<0,05 \text { yang } \\
\text { menunjukkan } \\
\text { bahwa promosi } \\
\text { dan inovasi produk } \\
\text { bersama-sama } \\
\text { berpengaruh } \\
\text { terhadap } \\
\text { keputusan } \\
\text { pembelian . }\end{array}$ \\
\hline $\begin{array}{l}\text { Gifani } \\
\text { Auliannisa, } \\
\text { Syahputra } \\
\text { Vol.10 No.2 } \\
2017\end{array}$ & $\begin{array}{l}\text { Pengaruh Citra } \\
\text { Merek } \\
\text { terhadap } \\
\text { keputusan } \\
\text { pemebelian } \\
\text { produk } \\
\text { smartphone } \\
\text { oppo pada }\end{array}$ & $\begin{array}{l}\text { (X1) sebagai } \\
\text { citra merek } \\
\text { dan (Y) } \\
\text { sebagai } \\
\text { keputusan } \\
\text { pembelian }\end{array}$ & $\begin{array}{l}\text { Kuantitatif, } \\
\text { analisis } \\
\text { Regresi }\end{array}$ & $\begin{array}{l}\text { Berdasarkan hasil } \\
\text { perhitungan } \\
\text { keseluruhan skor } \\
\text { awaban responden } \\
\text { mengenai variabel } \\
\text { itra merek, maka } \\
\text { lapat disimpulkan } \\
\text { pahwa jawaban }\end{array}$ \\
\hline
\end{tabular}




\begin{tabular}{|c|c|c|c|c|}
\hline & $\begin{array}{l}\text { mahasiswa } \\
\text { universitas } \\
\text { Telkom }\end{array}$ & & & $\begin{array}{lr}\text { esponden } & \text { tentang } \\
\text { itra merek } & \text { produk } \\
\text { pmartphone } & \text { oppo } \\
\text { ermasuk } & \text { dalam } \\
\text { kategori } & \text { baik } \\
\text { dengan persentase } \\
\text { sebesar } & 75,4 \% \text {. } \\
\text { Kemudian } & \text { hasil } \\
\text { perhitungan } & \\
\text { keseluruhan } & \text { skor } \\
\text { awaban responden } \\
\text { nengenai variabel } \\
\text { keputusan } \\
\text { pembelian, maka } \\
\text { dapat disimpulkan } \\
\text { pahwa jawaban } \\
\text { esponden } & \text { tentang } \\
\text { keputusan } & \\
\text { pembelian } & \text { produk } \\
\text { pmartphone } & \text { oppo } \\
\text { ermasuk } & \text { dalam } \\
\text { kategori } & \text { baik } \\
\text { dengan persentase } \\
\text { sebesar } 73,9 \% .\end{array}$ \\
\hline $\begin{array}{l}\text { Candra } \\
\text { Dery } \\
\text { Bagus, } \\
\text { dkk } \\
\text { (ISSN) }\end{array}$ & $\begin{array}{l}\text { Pengaruh } \\
\text { inovasi } \\
\text { produk dan } \\
\text { brand image } \\
\text { terhadapkep } \\
\text { keputusan } \\
\text { pembelian } \\
\text { pada olivia } \\
\text { cake }\end{array}$ & $\begin{array}{l}\text { (X1) sebagai } \\
\text { inovasi } \\
\text { produk, (X2) } \\
\text { sebagai } \\
\text { brand image } \\
\text { dan (Y) } \\
\text { sebagai } \\
\text { keputusan } \\
\text { pembelian }\end{array}$ & $\begin{array}{l}\text { Kuantitaif, } \\
\text { analisis } \\
\text { regresi } \\
\text { linier } \\
\text { berganda }\end{array}$ & $\begin{array}{l}\text { Hasil } r \\
\text { regresi linier } \\
\text { berganda } \\
\text { menunjukkan } \\
\text { persamaan Y = } \\
6,891+0,744 X 1 \\
+1,347 X 2 \text { dengan } \\
\text { koefisien } \\
\text { determinasinya } \\
\text { adalah 0,86. Hal } \\
\text { ini menunjukkan } \\
\text { bahwa presentase } \\
\text { sumbangan } \\
\text { pengaruh variabel } \\
\text { bebas sebesar } \\
\text { 86\% dan sisanya } \\
\text { sebesar 14\% } \\
\text { dipengaruhi } \\
\text { variabel lain yang } \\
\text { tidak dimasukkan } \\
\text { dalam penelitian } \\
\text { ini. Uji t }\end{array}$ \\
\hline
\end{tabular}




\begin{tabular}{|c|c|c|c|c|}
\hline & & & & 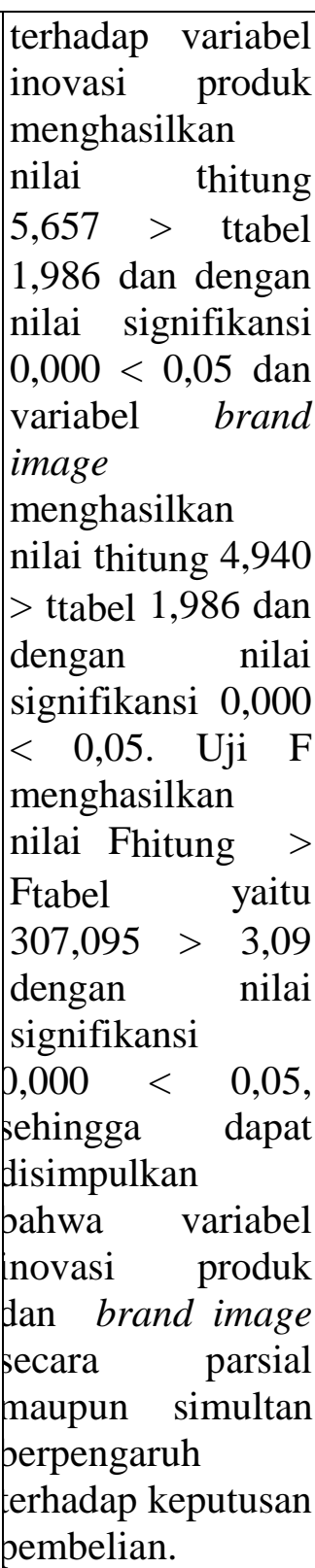 \\
\hline $\begin{array}{l}\text { Marheni } \\
\text { eka } \\
\text { Saputri, } \\
\text { Tutut ratna } \\
\text { pranata } \\
\text { Vol.13 } \\
\text { No.3 } \\
(2014)\end{array}$ & $\begin{array}{l}\text { Pengaruh } \\
\text { brand image } \\
\text { terhadap } \\
\text { kesetiaan } \\
\text { pengguna } \\
\text { Smartphone } \\
\text { Iphone }\end{array}$ & $\begin{array}{l}\text { (X1) sebagai } \\
\text { brand image } \\
\text { dan (Y) } \\
\text { sebagai } \\
\text { kesetiaan } \\
\text { pengguna } \\
\text { smertphone } \\
\text { iphone }\end{array}$ & $\begin{array}{l}\text { Kualitatif, } \\
\text { Analisis } \\
\text { deskriptif }\end{array}$ & $\begin{array}{l}\text { Berdasarkan } \\
\text { pengujian ecara } \\
\text { persial (Uji t), } \\
\text { hasil penelitian } \\
\text { membuktikan } \\
\text { tidak semua } \\
\text { indikator dari } \\
\text { variabel } \\
\text { independen brand } \\
\text { image } \\
\text { berpengaruh }\end{array}$ \\
\hline
\end{tabular}




\begin{tabular}{|c|c|c|c|c|}
\hline & & & & $\begin{array}{l}\text { positif dan } \\
\text { signifikan } \\
\text { terhadap variabel } \\
\text { dependen } \\
\text { loyalitas } \\
\text { pelanggan. }\end{array}$ \\
\hline $\begin{array}{l}\text { Rifki } \\
\text { Shaleh } \\
\text { (ISSN) } \\
\text { Vol.1 No.1 } \\
(2017)\end{array}$ & $\begin{array}{l}\text { Pengaruh } \\
\text { Inovasi Produk } \\
\text { Gaya Hidup, } \\
\text { Harga } \\
\text { Terhadap } \\
\text { Keputusan } \\
\text { Pembelian } \\
\text { Minyak } \\
\text { Rambut } \\
\text { Stalker } \\
\text { Pomade Di } \\
\text { UN Kediri }\end{array}$ & $\begin{array}{l}\text { Inovasi } \\
\text { produk } \\
\text { sebagai (X1), } \\
\text { gaya hidup } \\
\text { sebagai (X2), } \\
\text { harga } \\
\text { sebagai (X3) } \\
\text { dan } \\
\text { keputusan } \\
\text { pembelian } \\
\text { sebagai (Y). }\end{array}$ & $\begin{array}{l}\text { Kuantitatif, } \\
\text { analisis } \\
\text { regresi } \\
\text { linier } \\
\text { berganda }\end{array}$ & $\begin{array}{l}\text { Variabel kualitas } \\
\text { produk memiliki } \\
\text { nilai VIF sebesar } \\
\text { 4,813, variabel } \\
\text { komunikasi } \\
\text { interpersonal } \\
\text { memiliki nilai } \\
\text { VIF sebesar 5,449 } \\
\text { sedangkan untuk } \\
\text { variabel kualitas } \\
\text { pelayanan } \\
\text { memiliki nilai } \\
\text { VIF sebesar } \\
3,529 .\end{array}$ \\
\hline $\begin{array}{l}\text { Dwi ajeng } \\
\text { wulandari, } \\
\text { Farah } \\
\text { Oktafani } \\
\text { ISSN } \\
\text { Vol.11 } \\
\text { No.1 } \\
(2017)\end{array}$ & $\begin{array}{l}\text { Pengaruh } \\
\text { Brand image } \\
\text { terhadap } \\
\text { proses } \\
\text { keputusan } \\
\text { pembelian } \\
\text { sepatu Nike } \\
\text { pada } \\
\text { mahasiswa } \\
\text { komunkikasi } \\
\text { dan bisnis } \\
\text { Telkom } \\
\text { University } \\
\text { Bandung }\end{array}$ & $\begin{array}{l}\text { Brand Image } \\
\text { sebagai (X) } \\
\text { dan } \\
\text { keputusan } \\
\text { pembelian } \\
\text { sebagai (Y) }\end{array}$ & $\begin{array}{l}\text { Kuantitatif, } \\
\text { analisis } \\
\text { regresi } \\
\text { linier } \\
\text { sederhana }\end{array}$ & $\begin{array}{l}\text { Koefisien } \\
\text { determinasi } \mathrm{R}^{2} \\
\text { dapat diketahui } \\
\text { besarnya } \\
\text { pengaruh } \\
\text { vaariabel brang } \\
\text { image (X) } \\
\text { terhadap proses } \\
\text { keputusan } \\
\text { pembelian (Y) } \\
\text { adalah sebesar } \\
60,5 \% \text { sedangkan } \\
\text { sisanya sebesar } \\
39,5 \% \\
\text { dipengaruhi oleh } \\
\text { faktor lain. }\end{array}$ \\
\hline $\begin{array}{l}\text { Rasyid, } \\
\text { Tri Indah } \\
\text { ISSN } \\
\text { Vol.16 } \\
\text { No.1 } \\
(2018)\end{array}$ & $\begin{array}{l}\text { Pengaruh } \\
\text { inovasi } \\
\text { produk dan } \\
\text { harga } \\
\text { terhadap } \\
\text { keputusan } \\
\text { pembelian } \\
\text { sepeda motor } \\
\text { dikota }\end{array}$ & $\begin{array}{l}\text { Pengaruh } \\
\text { inovasi } \\
\text { produk } \\
\text { sebagai (X1) } \\
\text { harga } \\
\text { sebagai (X2) } \\
\text { dan } \\
\text { keputusan } \\
\text { pembelian }\end{array}$ & $\begin{array}{l}\text { Kuantitatif, } \\
\text { analisis uji } \\
\text { regresi } \\
\text { linier } \\
\text { sederhana }\end{array}$ & $\begin{array}{l}\text { Berdasarkan } \\
\text { pembahasan dan } \\
\text { pengujian- } \\
\text { pengujian yang } \\
\text { dilakukan, dapat di } \\
\text { simpulkan bahwa } \\
\text { Inovasi Produk } \\
\text { berpengaruh } \\
\text { positif dan } \\
\text { signifikan terhadap }\end{array}$ \\
\hline
\end{tabular}




\begin{tabular}{|c|c|c|c|c|}
\hline & $\begin{array}{l}\text { Tangerang } \\
\text { Selatan }\end{array}$ & sebagai (Y) & & $\begin{array}{l}\text { Keputusan } \\
\text { Pembelian Motor } \\
\text { Yamaha di } \\
\text { Tangerang } \\
\text { Selatan. Hal ini } \\
\text { menandakan } \\
\text { bahwa kebanyakan } \\
\text { pembeli dan } \\
\text { pengguna sepeda } \\
\text { motor Yamaha, } \\
\text { Tangerang } \\
\text { Selatan, artinya } \\
\text { keter- jangkuan } \\
\text { harga, kesesuaian } \\
\text { harga dengan } \\
\text { kualitas }\end{array}$ \\
\hline $\begin{array}{l}\text { Jalal } \\
\text { Hanaysha, } \\
\text { dkk. } \\
\text { Vol.4. } \\
\text { Edisi } 11 \\
(2014)\end{array}$ & $\begin{array}{l}\text { Efek } \\
\text { Langsung dan } \\
\text { Tidak } \\
\text { Langsung dari } \\
\text { Inovasi } \\
\text { Produk dan } \\
\text { Kualitas } \\
\text { Produk pada } \\
\text { Citra Merek: } \\
\text { Bukti Empiris } \\
\text { dari Industri } \\
\text { Otomotif }\end{array}$ & $\begin{array}{l}\text { Inovasi } \\
\text { produk (X1), } \\
\text { Kualitas } \\
\text { Produk (X2), } \\
\text { Kepercayaan } \\
\text { Merek (X3), } \\
\text { Citra Merek } \\
\text { sebagai } \\
\text { variabel (Y) }\end{array}$ & Regresi & $\begin{array}{l}\text { Dalam penelitian } \\
\text { ini, baik estimasi } \\
\text { langsung dan tidak } \\
\text { langsung dari } \\
\text { model yang } \\
\text { dihasilkan dihitung } \\
\text { untuk menguji } \\
\text { efek mediasi } \\
\text { kepercayaan } \\
\text { merek antara } \\
\text { inovasi produk dan } \\
\text { kualitas produk } \\
\text { dengan citra merek } \\
\text { (Preacher and } \\
\text { Hayes, 2008) } \\
\text { dengan 1000 } \\
\text { sampel bootstrap. } \\
\text { Seperti yang } \\
\text { disajikan pada } \\
\text { Tabel 1, interval } \\
\text { kepercayaan bias- } \\
\text { koreksi dilaporkan } \\
\text { pada tingkat 95\%. }\end{array}$ \\
\hline $\begin{array}{l}\text { Suhaily } \\
\text { Lily dan } \\
\text { Syarief } \\
\text { Darmoyo } \\
\text { Vol.21. } \\
\text { No.2 }\end{array}$ & $\begin{array}{l}\text { Pengaruh } \\
\text { Kualitas } \\
\text { Produk, } \\
\text { Harga } \\
\text { Persepsi } \\
\text { Dan Citra }\end{array}$ & $\begin{array}{l}\text { Kualitas } \\
\text { Produk (X1), } \\
\text { Persepsi } \\
\text { Harga (X2), } \\
\text { Citra Merek } \\
\text { (X3), dan }\end{array}$ & $\begin{array}{l}\text { Structural } \\
\text { Equation } \\
\text { Modeling } \\
\text { (SEM). }\end{array}$ & $\begin{array}{l}\text { Hasil penelitian } \\
\text { menunjukkan bahwa } \\
\text { terdapat kualitas } \\
\text { produk dan persepsi } \\
\text { harga berpengaruh }\end{array}$ \\
\hline
\end{tabular}




\begin{tabular}{|c|c|c|c|}
\hline (2017) & $\begin{array}{l}\text { Merek } \\
\text { Terhadap } \\
\text { Keputusan } \\
\text { Pembelian } \\
\text { Diperoleh } \\
\text { Kepercayaan } \\
\text { Pelanggan } \\
\text { (Studi Pada } \\
\text { Produk } \\
\text { Elektronik } \\
\text { Merek } \\
\text { Jepang) }\end{array}$ & $\begin{array}{l}\text { Keputusan } \\
\text { Pembelian } \\
\text { sebagai } \\
\text { variabel (Y) }\end{array}$ & $\begin{array}{l}\text { signifikan dan positi } \\
\text { terhadap keputusan } \\
\text { pembelian; kualitas } \\
\text { produk, citra merek, } \\
\text { dan harga yang } \\
\text { dipersepsikan } \\
\text { memiliki pengaruh } \\
\text { signifikan dan positi } \\
\text { terhadap kepercayaa } \\
\text { pelanggan. }\end{array}$ \\
\hline
\end{tabular}

\subsection{Kerangka Teorotik}

Gambar 2.1

Kerangka Teorotik

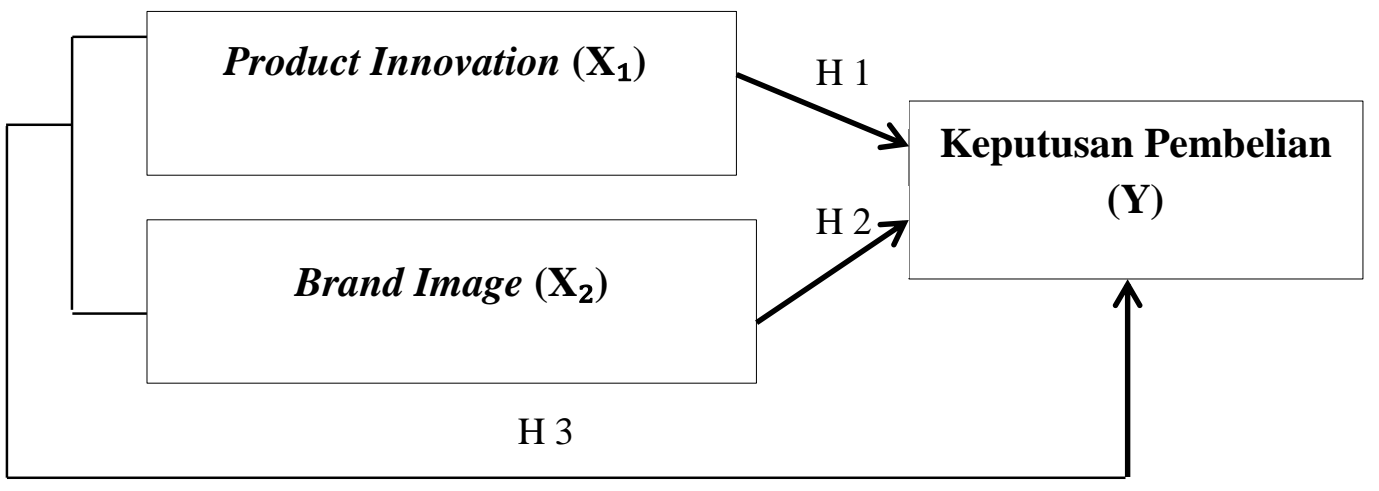

Keterangan :

X1 :Variabel pengaruh (Product Innovation)

X2 :Variabel pengaruh (Brand Image)

Y : Variabel terpengaruhi (Keputusan Pembelian)

$\longrightarrow \quad$ : Menunjukkan pengaruh variabel terhadap variabel terpengaruhi

$\longrightarrow$ :Garis pengaruh secara simultan 


\subsection{Definisi Operasional}

Tabel 2.2

Definisi Operasional Variabel

\begin{tabular}{|c|c|c|c|c|}
\hline Variabel & Definisi & Indikator & Alat Ukur & Skala \\
\hline $\begin{array}{l}\text { Keputusan } \\
\text { Pembelian } \\
\text { (Y) }\end{array}$ & $\begin{array}{l}\text { keputusan pembelian } \\
\text { merupakan sebuah } \\
\text { tahap dimana } \\
\text { pembeli telah } \\
\text { menentukan pilihan } \\
\text { untuk pengambilan } \\
\text { keputusan yang } \\
\text { diawali dengan } \\
\text { pengenalan masalah } \\
\text { kemudian } \\
\text { mengevaluasinya } \\
\text { dan memutuskan } \\
\text { produk yang paling } \\
\text { sesuai dengan } \\
\text { kebutuhan. }\end{array}$ & $\begin{array}{l}\text { 1. } \begin{array}{l}\text { Kemantapan } \\
\text { pada sebuah } \\
\text { produk. }\end{array} \\
\text { 2. } \text { Kebiasaan } \\
\text { dalam } \\
\text { memberi } \\
\text { produk. } \\
\text { 3. Memberikan } \\
\text { rekomendasi } \\
\text { kepada orang } \\
\text { lain. } \\
\text { 4. Melakukan } \\
\text { pembelian } \\
\text { ulang. } \\
\text { ( Kotler, 2009) } \\
\end{array}$ & Kusioner & Ordinal \\
\hline $\begin{array}{l}\text { Product } \\
\text { Innovation } \\
\left(\mathrm{X}_{1}\right)\end{array}$ & $\begin{array}{l}\text { product innovation } \\
\text { (inovasi produk) } \\
\text { adalah ide baru } \\
\text { berupa perubahan } \\
\text { desain, komponen } \\
\text { dan arsitektur } \\
\text { produk, dalam } \\
\text { menawarkan } \\
\text { produk yang } \\
\text { inovatif serta } \\
\text { peningkatan } \\
\text { pelayanan yang } \\
\text { menciptakan dan } \\
\text { memuaskan } \\
\text { pelanggan dalam } \\
\text { mencapai } \\
\text { keberhasilan. }\end{array}$ & $\begin{array}{l}\text { 1. } \begin{array}{l}\text { Perluasan lini } \\
\text { (line }\end{array} \\
\text { extensions) } \\
\text { 2. } \begin{array}{l}\text { Produk baru } \\
\text { (me too - }\end{array} \\
\text { product) } \\
\text { 3. } \text { Produk benar- } \\
\text { benar baru } \\
\text { (new - to - } \\
\text { the - world - } \\
\text { product) } \\
\text { Lukas dan } \\
\text { Ferrell (dalam } \\
\text { Dewi, 2006:18) }\end{array}$ & Kusioner & Ordinal \\
\hline $\begin{array}{l}\text { Brand } \\
\text { Image } \\
\left(\mathrm{X}_{2}\right)\end{array}$ & $\begin{array}{l}\text { brand Image (citra } \\
\text { merek), merupakan } \\
\text { suatu bentuk } \\
\text { asosiasi yang } \\
\text { bersifat positif atau }\end{array}$ & $\begin{array}{l}\text { 1. Citra koorporat } \\
\text { 2. Citra Produk } \\
\text { 3. Citra Pemakai } \\
\text { Menurut Biel } \\
\text { dalam jurnal }\end{array}$ & Kusioner & Ordinal \\
\hline
\end{tabular}




\begin{tabular}{|l|l|l|l|l|}
\hline & $\begin{array}{l}\text { negatif tergantung } \\
\text { pada persepsi } \\
\text { seseorang terhadap } \\
\text { suatu brand. }\end{array}$ & $\begin{array}{l}\text { penelitian } \\
\text { Sulistiya } \\
\text { Ningsih } \\
\text { (Evawati, 2012) }\end{array}$ & & \\
\hline
\end{tabular}

\subsection{Hipotesis}

Berdasarkan latar belakang dan landasan teori, perumusan masalah serta penelitian terdahulu, maka penulis mengajukan hipotesis yang merupakan kesimpulan sementara bagaimana dua variabel bebas terhadap satu variabel terikat dalam penulisan hipotesis ini yaitu sebagai berikut:

$\mathrm{H}_{1}=$ Product Innovation $\left(\mathrm{X}_{1}\right)$ berpengaruh positif terhadap keputusan pembelian produk Smartphone Oppo pada konsumen di Toko Jaya Ponsel Cabang Simpang SKIP Kota Bengkulu.

$\mathrm{H}_{2}=$ Brand Image $\left(\mathrm{X}_{2}\right)$ berpengaruh positif terhadap keputusan pembelian produk Smartphone Oppo pada konsumen di Toko Jaya Ponsel Cabang Simpang SKIP Kota Bengkulu.

$\mathrm{H}_{3}=$ Product Innovation $\left(\mathrm{X}_{1}\right)$ dan Brand Image $\left(\mathrm{X}_{2}\right)$ secara bersamaan berpengaruh positif terhadap keputusan pembelian produk Smartphone Oppo pada konsumen di Toko Jaya Ponsel Cabang Simpang SKIP Kota Bengkulu. 


\section{BAB III \\ METODE PENELITIAN}

\subsection{Tempat Dan Waktu Penelitian}

Penelitian ini dilakukan pada konsumen Smartphone OPPO di Toko Jaya Ponsel, yang terletak di Jl. S. Parman Simpang SKIP Kota Bengkulu. Adapun penelitian ini akan dilaksanakan dari bulan Februari 2020 sampai dengan selesai.

\subsection{Metode Penelitian}

Jenis Penelitian yang dilakukan dalam penelitian ini adalah penelitian metode kuantitatif. Dalam penelitian kuantitatif, yang dilandasi pada suatu asumsi bahwa suatu gejala itu dapat diklasifikasikan, dan hubungan gejala bersifat kausal (sebab akibat). Bentuk hipotesis dari penelitian ini adalah asosiatif yaitu mencari hubungan antara dua variabel atau lebih (Sugiyono, 2012:13). Penelitian ini dimaksudkan untuk mengetahui seberapa pengaruh variabel-variabel bebas terhadap variable terikatnya, serta mengetahui bagaimana hubungan itu terjadi. Data yang digunakan dalam penelitian ini adalah data dalam bentuk data primer yang merupakan Keputusan Pembelian produk Smartphone Oppo.

\subsection{Populasi dan Sampel}

\subsubsection{Populasi}

Populasi adalah wilayah yang terdiri atas objek atau subjek yang mempunyai produktivitas dan karakteristik tertentu yang ditetapkan oleh peneliti untuk dipelajari dan ditarik kesimpulannya, (Sugiyono, 2010). Populasi adalah 
“obyek yang akan diteliti dalam suatu penelitian” (Onsardi, 2019). Populasi dalam penelitian ini adalah konsumen yang berkunjung di Toko Jaya Ponsel Cabang Simpang SKIP Kota Bengkulu. Data ini diambil pada bulan februari sampai dengan maret 2020.

\subsubsection{Sampel}

Sampel adalah suatu bagian dari populasi tertentu yang menjadi perhatian (Suyarhadi dan Purwanto, 2004:323). Sampel adalah "bagian dari populasi yang reprentatif, artinya sampel itu adalah wakil populasi yang akan diteliti" (Onsardi, 2018, Asmawi, 2017, Anjani, 2019). Sampel dalam penelitian ini adalah konsumen yang melakukan pemebelian produk smartphone oppo yang berada di Toko Jaya Ponsel yang mempunyai karakteristik yang sesuai dengan yang dibutuhkan dalam penelitian dan dapat dijadikan sebagai responden. Penetuan jumlah sampel yang representative menurut Hair, et al. (1995 dalam Kiswati 2010) adalah tergantung pada jumlah indikator dikali 5 sampai 10. Jumlah sampel dalam penelitian ini adalah :

Sampel $=$ jumlah indikator $\mathrm{x} 10=10 \times 10=100$ reponden

Berdasarkan perhitungan diatas didapat untuk sampel menggunakan 100 sampel responden.

\subsection{Teknik Pengumpulan Data}

Data yang digunakan dalam penelitian ini adalah data primer. Data Primer adalah data yang berasal dari sumber asli atau pertama (Sugiyono, 2012). Pengumpulan data dalam penelitian ini dilakukan dengan menggunakan metode survei berupa : 


\section{Observasi}

Observasi merupakan suatu teknik pengumpulan data dengan jalan mengadakan pengamatan terhadap kegiatan yang sedang berlangsung. Adapun jenis observasi yang peniliti gunakan untuk mendapatkan data yang diperlukan guna mengetahui tujuan penelitian ini adalah pembelian produk smartphone oppo oleh konsumen Toko Jaya Ponsel.

\section{Wawancara}

Wawancara merupakan pertemuan dua orang untuk bertukar informasi dan ide melalui tanya jawab sehingga dapat dikontruksikan makna tanya jawab dalam suatu topik tertentu (Sugiyono, 2012). Wawancara dilakukan dengan karyawan dan konsumen smartphone oppo di Toko Jaya Ponsel Cabang simpang SKIP Kota Bengkulu.

\section{Kusioner}

Kusioner merupakan teknik pengumpulan data yang dilakukan dengan cara memberikan seperangkat pertanyaan tertulis kepada responden untuk di isi atau dijawab (Sugiyono, 2012). Pengajuan kuesioner ini dilakukan dengan mengajukan daftar pertanyaan tertulis dalam suatu daftar pertanyaan kepada responden. Dengan cara sebagai berikut :

a) Membagikan kuesioner

b) Responden diminta mengisi kuesioner pada lembar jawaban yang telah disediakan

c) Kemudian lembar kuesioner dikumpulkan, diseleksi, diolah, dan kemudian dianalisis. 
Skala pengukuran data dalam penelitian ini adalah skala ordinal sebagai alat untuk mengukur sikap, pendapat dan persepsi seseorang atau kelompok orang tentang variabel-variabel yang akan diuji, dan pada setiap jawaban akan diberi skor, (Sugiyono, 2010). Skor yang akan diberi untuk setiap variabel seperti berikut :

Tabel 3.1

Skala Ordinal

\begin{tabular}{|c|l|c|}
\hline No. & \multicolumn{1}{|c|}{ Pertanyaan } & Bobot \\
\hline 1 & Sangat Setuju (SS) & 5 \\
\hline 2 & Setuju (S) & 4 \\
\hline 3 & Normal (N) & 2 \\
\hline 4 & Tidak Setuju (TS) & 1 \\
\hline 5 & Sangat Tidak Setuju (STS) & \\
\hline
\end{tabular}

Tabel 3.2

Kisi-Kisi Kusioner

\begin{tabular}{|c|c|c|c|c|}
\hline No. & Variabel & Indikator & Butir & $\sum$ \\
\hline 1 & $\begin{array}{l}\text { Product Innovation } \\
\left(\mathrm{X}_{1}\right)\end{array}$ & $\begin{array}{l}\text { 4. Perluasan lini (line } \\
\text { extensions) } \\
\text { 5. Produk baru (me too- } \\
\text { product) } \\
\text { 6. Produk benar-benar baru } \\
\text { (new - to - the - world } \\
\text { - product) }\end{array}$ & $\begin{array}{l}1-2 \\
3-4 \\
5-6\end{array}$ & $\begin{array}{l}2 \\
2 \\
2\end{array}$ \\
\hline & & & Jumlah & 6 \\
\hline 2 & $\begin{array}{l}\text { Brand Image } \\
\left(\mathrm{X}_{2}\right)\end{array}$ & $\begin{array}{ll}\text { 1. } & \text { Citra Koorporat } \\
\text { 2. } & \text { Citra Produk } \\
\text { 3. } & \text { Citra Pemakai }\end{array}$ & $\begin{array}{l}7-8 \\
9-10 \\
11-12\end{array}$ & $\begin{array}{l}2 \\
2 \\
2\end{array}$ \\
\hline
\end{tabular}




\begin{tabular}{|c|c|c|c|c|}
\hline & & & & \\
\hline & & & Jumlah & 6 \\
\hline \multirow[t]{2}{*}{3} & $\begin{array}{l}\text { Keputusan } \\
\text { Pembelian } \\
\text { (Y) }\end{array}$ & $\begin{array}{l}\text { 5. Kemantapan pada sebuah } \\
\text { produk. } \\
\text { 6. Kebiasaan dalam } \\
\text { membeli produk. } \\
\text { 7. Memberikan } \\
\text { rekomendasi kepada } \\
\text { orang lain. } \\
\text { 8. Melakukan pembelian } \\
\text { ulang. }\end{array}$ & $\begin{array}{l}15-16 \\
17-18 \\
19-20 \\
21-22\end{array}$ & $\begin{array}{l}2 \\
2 \\
2 \\
2\end{array}$ \\
\hline & & & Jumlah & 8 \\
\hline
\end{tabular}

\subsection{Uji Instrumen}

\subsubsection{Uji Validitas}

Uji validitas dilakukan untuk mengetahui apakah suatu instrument alat ukur telah menjalankan fungsi ukurnya. Menurut Sekaran (2003) dalam Wijaya (2013:88). Hasil penelitian yang valid bila terdapat kesamaan antara data yang terkumpul dengan data yang sesungguhnya terjadi pada obyek yang di teliti. Instrumen yang valid berarti alat ukur yang digunakan untuk mendapatkan data (mengukur) itu valid. Valid berarti instrument tersebut dapat digunakan untuk mengukur apa yang seharusnya diukur (Sugiyono, 2007:172). Alat untuk mengukur validitas adalah Korelasi Product Moment dari Pearson (Arikunto, 2006: 170). Suatu indikator dikatakan valid, apabila: $\mathrm{n}=50$ dan $\alpha=0,05$, maka $\mathrm{r}$ tabel $=$ dengan ketentuan $($ Arikunto,2006:184):

Hasil $\mathrm{r}$ hitung $>\mathrm{r}$ tabel $=$ Valid

Hasil $\mathrm{r}$ hitung $>\mathrm{r}$ tabel $=$ Tidak valid

$$
r=\frac{N\left(\sum X Y\right)-\left(\sum X\right)\left(\sum Y\right)}{\sqrt{\left.\left[n \sum X^{2}-\left(\sum X\right)^{2}\right]\left[n \sum Y\right)^{2}\right]}}
$$


Keterangan:

$\mathrm{r}=$ Kolerasi Produk Moment X dan Y

$\mathrm{X}=$ Nilai Variabel $\mathrm{X}$

$\mathrm{Y}=$ Nilai Variabel $\mathrm{Y}$

$\mathrm{n}=$ Banyaknya Sampel

Menurut Sugiyono (2013 : 208) bila koefisien korelasi sama dengan 0,3 atau lebih, maka butir instrumen dinyatakan valid. Pengujian validitas dalam penelitian ini menggunakan komputer dengan bantuan program SPSS Versi 20. Uji validitas pada 20 orang responden pada konsumen smartphone OPPOpada Toko Jaya Ponsel Simpang Skip Kota Bengkulu, hasil pengujian dapat dilihat pada lampiran 3 .

Tabel 3.3

Ringkasan Hasil uji Validitas variabel Product Innovation, Brand Image dan Keputusan Pembelian pada konsumen smartphone OPPO

Keputusan Pembelian (Y)

\begin{tabular}{|c|c|c|c|c|}
\hline \multirow{4}{*}{ Variabel } & No. Pernyataan & R. Hitung & $\mathbf{R}$ & Keterangan \\
\hline \multirow{4}{*}{ Product Innovation (X1) } & 1 & 0,78 & 0,3 & Valid \\
\cline { 2 - 5 } & 2 & 0,58 & 0,3 & Valid \\
\cline { 2 - 5 } & 3 & 0,39 & 0,3 & Valid \\
\cline { 2 - 5 } & 4 & 0,7 & 0,3 & Valid \\
\cline { 2 - 5 } & 5 & 0,79 & 0,3 & Valid \\
\cline { 2 - 5 } & 6 & 0,5 & 0,3 & Valid \\
\hline \multirow{3}{*}{ Brand Image $(X 2)$} & 1 & 0,72 & 0,3 & Valid \\
\cline { 2 - 5 } & 2 & 0,63 & 0,3 & Valid \\
\cline { 2 - 5 } & 3 & 0,33 & 0,3 & Valid \\
\hline
\end{tabular}




\begin{tabular}{|c|c|c|c|c|}
\hline & 4 & 0,66 & 0,3 & Valid \\
\hline & 5 & 0,83 & 0,3 & Valid \\
\hline & 6 & 0,46 & 0,3 & Valid \\
\hline \multirow{8}{*}{ Keputusan Pembelian ( $Y)$} & 1 & 0,93 & 0,3 & Valid \\
\hline & 2 & 0,86 & 0,3 & Valid \\
\hline & 3 & 0,86 & 0,3 & Valid \\
\hline & 4 & 0,54 & 0,3 & Valid \\
\hline & 5 & 0,93 & 0,3 & Valid \\
\hline & 6 & 0,84 & 0,3 & Valid \\
\hline & 7 & 0,58 & 0,3 & Valid \\
\hline & 8 & 0,43 & 0,3 & Valid \\
\hline
\end{tabular}

\section{Sumber : Hasil Penelitian Dan Data Diolah 2020}

Berdasarkan tabel diatas hasil uji validitas dapat dilihat bahwa $\mathrm{R}$ hitung lebih besar dari r yaitu lebih besar dari 0,30. Maka dari 20 pernyataan yang di uji semua item valid.

\subsubsection{Uji Reliabilitas}

Uji reliabilitas dimaksudkan untuk mengetahui sejauh mana hasil pengukuran tetap konsisten apabila dilakukan pengukuran dua kali atau lebih terhadap pernyataan yang sama menggunakan alat ukur yang sama pula. Uji reliabilitas dalam penelitian ini menggunakan teknik Cronbach's Alpha $(\alpha)$, dimana suatu instrumen dapat dikatakan handal (reliabel), bila memiliki cronbach's alpha $\geq 0,6$ (Ghozali, 2005).

Tabel 3.4

Ringkasan Hasil Nilai Cronbach Alpa Dari Tiap Variabel

\begin{tabular}{|c|l|c|c|}
\hline Variabel & Pernyataan & $\begin{array}{c}\text { Cronbach's } \\
\text { Alpha }\end{array}$ & Keterangan \\
\hline
\end{tabular}




\begin{tabular}{|c|c|c|c|}
\hline \multirow{6}{*}{ Product Innovation (X1) } & 1 & \multirow{6}{*}{0,74} & Reliabel \\
\hline & 2 & & Reliabel \\
\hline & 3 & & Reliabel \\
\hline & 4 & & Reliabel \\
\hline & 5 & & Reliabel \\
\hline & 6 & & Reliabel \\
\hline \multirow{6}{*}{ Brand Image (X2) } & 1 & \multirow{6}{*}{0,73} & Reliabel \\
\hline & 2 & & Reliabel \\
\hline & 3 & & Reliabel \\
\hline & 4 & & Reliabel \\
\hline & 5 & & Reliabel \\
\hline & 6 & & Reliabel \\
\hline \multirow{8}{*}{ Keputusan Pembelian (Y) } & 1 & \multirow{8}{*}{0,79} & Reliabel \\
\hline & 2 & & Reliabel \\
\hline & 3 & & Reliabel \\
\hline & 4 & & Reliabel \\
\hline & 5 & & Reliabel \\
\hline & 6 & & Reliabel \\
\hline & 7 & & Reliabel \\
\hline & 8 & & Reliabel \\
\hline
\end{tabular}

Dari tabel 3.4 diatas terlihat bahwa semua variabel memiliki nilai cronbach alpa lebih besar dari 0,60 maka dapat disimpulkan bahwa semua variabel ini dikatakan Reliabel.

\subsection{Teknik Analisis Data}

\subsubsection{Analisis Deskriptif}


Menurut Sugiyono (2004:169) Analisis deskriptif adalah statistik yang digunakan untuk menganalisa data dengan cara mendeskripsikan atau menggambarkan data yang telah terkumpul sebagaimana adanya tanpa bermaksud membuat kesimpulan yang berlaku untuk umum atau generalisasi. Menurut Sugiyono (2005: 21) menyatakan bahwa metode deskriptif adalah suatu metode yang digunakan untuk menggambarkan atau menganalisis suatu hasil penelitian tetapi tidak digunakan untuk membuat kesimpulan yang lebih luas.

Jadi, menurut pendapat diatas, analisis deskriptif adalah bagian dari statistik yang digunakan untuk manggambarkan atau mendeskripsikan data tanpa bermaksud mengenaralisir atau membuat kesimpulan tapi hanya menjelaskan kelompok data itu saja.

\subsection{Uji Asumsi Klasik}

Sebelum pengujian hipotesis dilakukan, terlebih dahulu perlu dilakukan pengujian-pengujian terhadap gejala penyimpangan asumsi klasik. Asumsi model linear klasik adalah tidak terdapat multikolinearitas, heteroskedasitas dan data terdistribusi secara normal. Cara yang digunakan untuk menguji gejala penyimpangan asumsi klasik sebagai berikut (Ghozali, 2011) :

\subsubsection{Uji Normalitas}

Pengujian normalitas bertujuan untuk menguji apakah dalam model regresi, variabel pengganggu atau residual memiliki distribusi normal. Modelregresi yang baik mempunyai distribusi yang normal atau mendekati normal.

Pengujian normalitas dilakukan dengan cara : 
a. Melihat Normal Probability Plot yang membandingkan distribusi kumulatif dari data sesungguhnya dengan distribusi kumulatif dari distribusi normal. Data sesungguhnya diplotkan sedangkan distribusi normal akan membentuk garis diagonal. Apabila data distribusi normal maka plot data akan mengikuti garis diagonal (Ghozali, 2011).

b. Melihat histogram yang membandingkan data sesungguhnya dengan data distribusi normal.

\subsubsection{Uji Multikolinieritas}

Uji ini bertujuan untuk menguji apakah model regresi ditemukan adanya korelasi antar variabel bebas (independen). Model regresi yang baik seharusnya tidak terjadi korelasi diantara variabel independen. Jika variabel independen saling berkorelasi, maka variabel-variabel ini tidak ortogonal. Variabel ortogonal adalah variabel independen yang nilai korelasi antar sesama variabel independen sama dengan nol (Ghozali, 2011:105).

Multikolonieritas dapat dilihat dari (1) nilai toleransi dan lawannya (2) varience inflation factor (VIF). Torelance mengukur variabilitas independen lainnya. Jika nilai tolerance yang rendah sama dengan nilai VIF tinggi (karena $\mathrm{VIF}=1$ /tolerance $)$. Nilai cut off yang umum dipakai untuk menunjukan adanya multikolinieritas adalah nilai tolerance 0,10 atau sama dengan nilai VIF 10 , (Ghozali, 2011:106).

\subsubsection{Uji Heteroskedastisitas}


Bertujuan menguji apakah dalam model regresi terjadi ketidaksamaan variance dari residual satu pengamatan ke pengamatan yang lain. Jika variance dari residual satu pengamatan ke pengamatan lain tetap, maka disebut Homoskedastisitas dan jika berbeda disebut Heteroskedastisitas. Model regresi yang baik adalah yang Homoskedastisitas atau tidak terjadi Heteroskedastisitas (Ghozali, 2016). Dalam penelitian ini, cara untuk mendeteksi ada atau tidaknya heteroskedastisitas adalah dengan melihat Grafik Plot antara nilai prediksi variabel terikat (dependen) dengan residualnya. Deteksi ada tidaknya heteroskedastisitas dapat dilakukan dengan melihat ada tidaknya pola tertentu pada grafik scatterplot antara keduanya dimana sumbu $\mathrm{Y}$ adalah $\mathrm{Y}$ yang telah diprediksi, dan sumbu $\mathrm{X}$ adalah residual (Y prediksi - Y sesungguhnnya) yang telah di-studentized. Dasar analisis (Ghozali, 2013):

1. Jika ada pola tertentu, seperti titik-titik yang ada membentuk pola tertentu yang teratur (bergelombang, melebar kemudian menyempit), maka mengindikasikan telah terjadi heteroskedastisitas.

2. Jika tidak ada pola yang jelas, serta titik-titik yang menyebar di atas dan di bawah angka 0 pada sumbu $\mathrm{Y}$, maka tidak terjadi heteroskedastisitas.

\subsection{Analisis Regresi Berganda}

Metode regresi berganda dipandang mampu menghubungkan dua variabel independen dengan satu variabel dependen dalam suatu model prediktif tungal. Persamaan regresinya sebagai berikut :

$\mathbf{Y}=\mathbf{a}+\mathbf{b}_{\mathbf{1}} \mathbf{X}_{\mathbf{1}}+\mathbf{b}_{\mathbf{2}} \mathbf{X}_{\mathbf{2}}+\mathbf{e},($ Sugiyono, 2013) 
Dimana:

Y : Keputusan Pembelian

a : Konstanta Regresi

$\mathrm{X}_{1}$ : Product Innovation

$\mathrm{X}_{2}$ : Brand Image

$\mathrm{b}_{1}, \mathrm{~b}_{2}:$ Koefisien Variabel Independen

e : error

\subsection{Koefisien Uji Determinasi $\left(\mathbf{R}^{2}\right)$}

Pengujian koefisien determinasi digunakan untuk mengukur seberapa besar pengaruh dari seluruh variabel dependen yang ada dan besarnya pengaruh yang disebabkan oleh variabel lain tidak dapat dijelaskan. Hal ini ditunjukan oleh bessarnya koefisien determinan $\left(\mathrm{R}^{2}\right)$ yang besarnya antara 0 sampai dengan 1 atau $0 \leq \mathrm{R}^{2} \leq 1$. Jika $\mathrm{R}^{2}$ mendekati 1 , maka variabel independen berpengaruh signifikan terhadap variabel dependen dengan sempurna atau terdapat suatu kecocokan yang sempurna (variabel independen yang dipakai dapat menerangkan dengan baik variabel dependen). Namun jika koefisien determinasi adalah nol (0) berarti variabel independen tidak berpengaruh terhadap variabel dependen (Sugiyono, 2010:115).

Koefisien determinasi dalam penelitian ini adalah mengukur pengaruh Product Innovation $\left(\mathrm{X}_{1}\right)$ dan Brand Image $\left(\mathrm{X}_{2}\right)$, terhadap Keputusan Pembelian (Y). Dalam penlitian ini untuk mengolah data digunakan alat bantu SPSS (Statistic Package for the Social Science). 


\subsection{Uji Hipotesis}

Uji hipotesis bertujuan untuk mengetahui apakah ada atau tidaknya pengaruh yang signifikan antara variabel Independen (Product Innovation dan Brand Image) terhadap variabel dependen (Keputusan Pembelian) baik secara simultan maupun persial.

\subsubsection{Uji Hipotesis (Uji t)}

Uji hipotesis $\mathrm{t}($ t test) digunakan untuk menguji apakah koefisien regresi persial berbeda secara signifikan dari nol atau apakah suatu variabel bebas secara individu berpengaruh terhadap variabel terikatnya. Kriteria pengambilan keputusannya dilakukan dengan membandingkan nilai statistik $\mathrm{t}$ dengan titik kritis menurut tabel. Apabila nilai statistik t hasil perhitungan lebih tinggi dibandingkan nilai t tabel. Ha yang menyatakan bahwa suatu variabel independen secara individual mempengaruhi variabel dependen diterima. Taraf nyata atau level of signifikan $(\alpha)$ yang digunakan adalah 5\% $(0,05)$.

Uji t digunakan untuk mengetahui masing-masing sumbangan variabel bebas secara persial terhadap variabel terikat. Uji hipotesis ini dilakukan dengan cara membandingkan nilai $\mathrm{t}$ hitung dengan nilai $\mathrm{t}$ tabel tingkat keyakinan $95 \%$ atau $\alpha=0,05$.

Dengan langkah pengujian sebagai berikut :

1. Jika $\mathrm{t}$ sig $>0,05$ Ho diterima, Ha ditolak, berarti secara sendiri-sendiri (persial) tidak ada pengaruh variabel Product Innovation $\left(\mathrm{X}_{1}\right)$, dan Brand Image $\left(\mathrm{X}_{2}\right)$, terhadap variabel terikatnya yaitu Keputusan Pembelian (Y). 
2. Jika $\mathrm{t}$ sig $<0,05$ Ho ditolak, Ha diterima berarti secara sendiri-sendiri (persial) ada pengaruh Product Innovation $\left(\mathrm{X}_{1}\right)$ dan Brand Image $\left(\mathrm{X}_{2}\right)$ terhadap variabel terikatnya yaitu Keputusan Pembelian (Y).

\subsubsection{Uji Hipotesis (Uji F)}

Uji F ( F test) bertujuan untuk mengetahui kelayakan model regresi linier berganda sebagai alat analisis yang menguji pengaruh variabel independen terhadap variabel dependen. Bila nilai $F$ (signifikansi anova) $<\alpha(5 \%)$, maka model layak atau fit, namun sebaliknya bila nilai $\mathrm{F}$ (signifikansi anova) > (5\%), maka model tidak layak.

Uji F digunakan untuk melihat secara bersama - sama pengaruh variabel bebas yaitu variabel Product Innovation $\left(\mathrm{X}_{1}\right)$ dan Brand Image $\left(\mathrm{X}_{2}\right)$ terhadap variabel terikatnya yaitu Keputusan Pembelian (Y). Pada taraf keyakinan 95\% atau $\alpha=0,05$. Adapun kriteria pengujian sebagai berikut :

1. Jika $\mathrm{f}$ sig $>0,05$ Ho diterima, Ha ditolak berarti tidak ada pengaruh secara bersamaan (Simultan) variabel Product Innovation $\left(\mathrm{X}_{1}\right)$ dan Brand Image $\left(\mathrm{X}_{2}\right)$ terhadap varibel terikatnya yaitu Keputusan Pembelian (Y).

2. Jika $\mathrm{f}$ sig $<0,05$ Ho ditolak, Ha diterima berarti ada pengaruh secara bersamaan (simultan) variabel Product Innovation $\left(\mathrm{X}_{1}\right)$ dan Brand Image $\left(\mathrm{X}_{2}\right)$ terhadap variabel terikatnya yaitu Keputusan Pembelian (Y). 


\section{BAB IV \\ HASIL DAN PEMBAHASAN}

\subsection{Hasil}

Bagian ini akan menjelaskan mengenai hal-hal yang berkaitan dengan datadata yang berhasil dikumpulkan, hasil pengolahan data dan pembahsan dari hasil pengelolahan data. Sistematika pembahasan dalam bab ini terdiri dari sejarah singkat perusahaan, struktur organisasi, karakteristik responden, deskripsi tanggapan respoonden, uji asumsi klasik, analisis linear berganda, koefisien determinasi, uji F dan Uji t.

\subsubsection{Sejarah Singkat Toko Jaya Ponsel Simpang SKIP Bengkulu}

Toko Jaya Ponsel merupakan salah satu Toko yang menjual berbagai merek Smartphone diantaranya yaitu smartphone OPPO. Toko Jaya Ponsel sendiri diresmikan pada tanggal 27 November 2013 di Jakarta oleh H. Willi Handoko. Sedangkan Toko Jaya Ponsel cabang Simpang Skip Kota Bengkulu didirikan oleh Dona Bateresia dan resmi berdiri pada tanggal 1 Maret 2019. Seiring berjalannya waktu pertumbuhan penjualan pada Toko Jaya Ponsel mengalami kenaikan sehingga mampu mendirikan dan memiliki banyak cabang diantaranya Padang, Bengkulu, Bekasi dan beberapa daerah lainnya yang tersebar di Indonesia. Toko Jaya Ponsel sendiri memiliki nama induk Jaya Ponsel Indonesia, sedangkan di Kota Bengkulu sendiri ada empat cabang yaitu cabang di Simpang Skip sendiri, Lingkar Timur, Suprapto dan Kampung Bali. Jumlah karyawan di Toko Jaya 
Ponsel Cabang Simpang Skip memiliki 26 karyawan termasuk promotor dari masing brand smartphone yang ditawarkan.

\subsubsection{Visi dan Misi Toko Jaya Ponsel Simpang SKIP Bengkulu}

Adapun Visi dan Misi Toko Jaya Ponsel Simpang SKIP Bengkulu sebagai berikut :

1. Visi

Menjadikan Toko Jaya Ponsel sebagai Toko handphone yang unggul dan terpercaya.

2. Misi

Memberikan pelayanan yang terbaik, nyaman dan menyenangkan bagi konsumen.

\subsubsection{Struktur Organisasi Toko Jaya Ponsel Simpang SKIP Kota Bengkulu}

Struktur merupakan cara organisasi mengatur sumber daya manusia bagi kegiatan-kegiatan kearah tujuan. Bagi pengelola organisasi struktur organisasi pada hakikatnya adalah suatu cara untuk menata unsur-unsur dalam organisasi dengan sebaik-baiknya, demi mencapai berbagai tujuan yang telah ditetapkan (Kusdo, 2009:176).

Struktur organisasi merupakan salah satu alat untuk mencapai tujuan secara efektif. Struktur organisasi yang bai akan memudahkan koordinasi dan komunikasi atas semuayang merangkap jabatan, untuk lebih jelasnya dapat dilihat pada struktur organisasi Toko Jaya Ponsel dibawah ini. 
4.1

STRUKTUR ORGANISASI

Toko Jaya Ponsel Cabang Skip Bengkulu

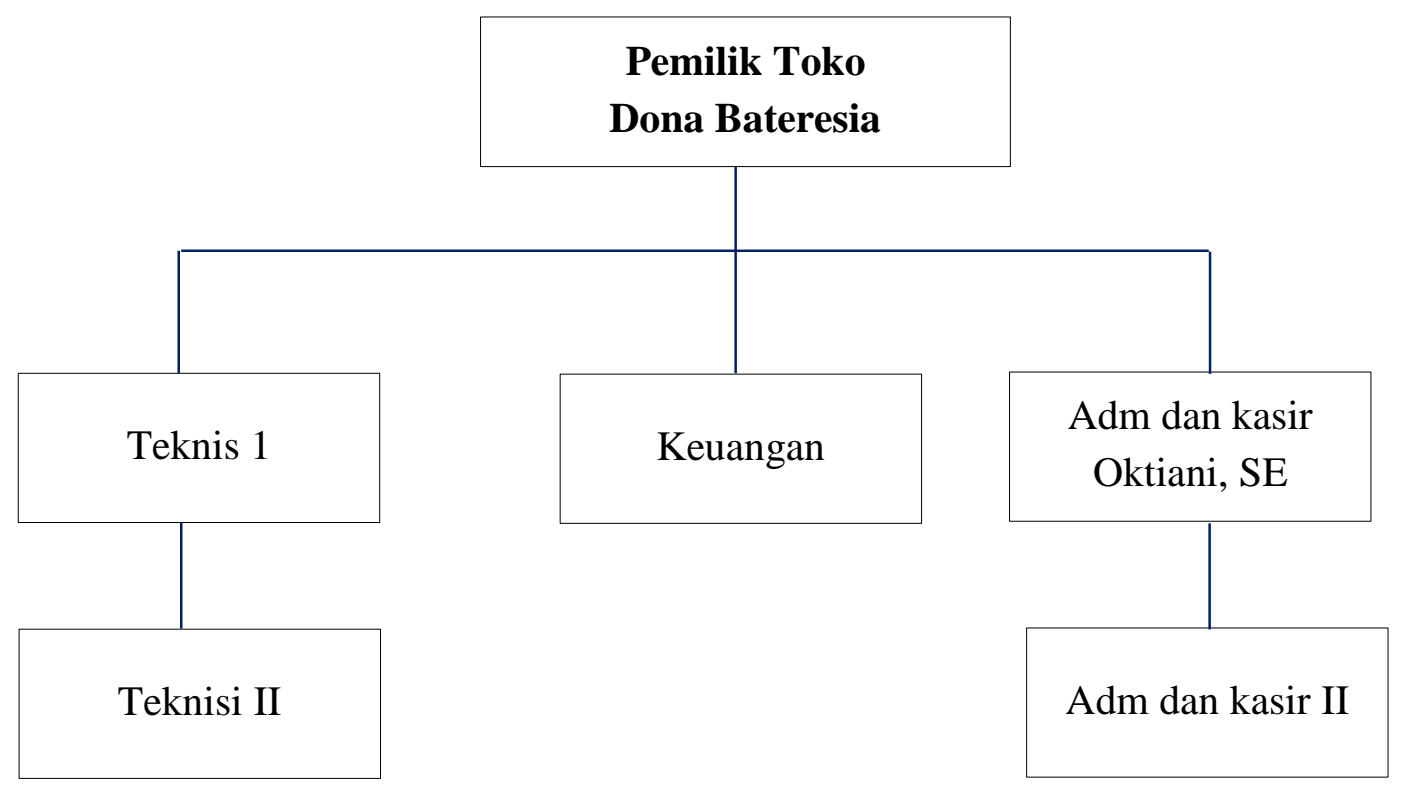

\subsubsection{Karakteristik Responden}

Responden yang menjadi subjek pada penelitian ini Pada Konsumen Produk Smartphone Oppo pada Toko Jaya Ponsel Cabang Simpang Skip Kota Bengkulu. Dari hasil pengumpulan data melalui koesioner terhadap 100 orang yang dijadikan responden penelitian, maka dapat diketahui karakteristik responden berdasarkan jenis kelamin, usia, dan pendidikan terakhir.

\subsubsection{Karakteristik Responden Berdasarkan Jenis Kelamin}

Jumlah responden berdasarkan jenis kelamin yang ada pada Pada Konsumen Produk Smartphone Oppo pada Jaya Ponsel Cabang Simpang Skip Kota Bengkulu dapat dilihat pada tabel 4.1 
Tabel 4.1

Karakteristik Responden Berdasarkan jenis Kelamin

\begin{tabular}{|l|l|l|}
\hline Jenis Kelamin & Frekuensi & Persentase \\
\hline Laki-laki & 88 & $88,23 \%$ \\
\hline Perempuan & 12 & $11,77 \%$ \\
\hline Total & 100 & $100 \%$ \\
\hline
\end{tabular}

Sumber: Data yang diolah 2020

Berdasarkan tabel di atas diketahui karakteristik responden berdasarakan jenis kelamin laki-laki sebanyak 100 orang responden atau $88.23 \%$, kemudian jumlah responden perempuan sebanyak 12 orang responden atau $11,77 \%$. Dari data tersebut menyatakan bahwa Pada Konsumen Produk Smartphone Oppo pada Toko Jaya Ponsel Cabang Simpang Skip Kota Bengkulu lebih banyak laki-laki daripada perempuan yang berbelanja pada Konsumen Produk Smartphone Oppo pada Toko Jaya Ponsel Cabang Simpang Skip Kota Bengkulu.

\subsubsection{Karakteristik Responden Berdasarkan Usia}

Jumlah responden berdasarkan usia yang ada pada Pada Konsumen Produk Smartphone Oppo pada Jaya Ponsel Cabang Simpang Skip Kota Bengkulu dapat dilihat pada tabel 4.2

Tabel 4.2

Karakteristik Responden Berdasarkan Usia

\begin{tabular}{|l|l|l|}
\hline Usia & Frekuensi & Persentase \\
\hline$<20$ & 19 & $18,6 \%$ \\
\hline $20-29$ & 31 & $30,7 \%$ \\
\hline $30-40$ & 39 & $39,3 \%$ \\
\hline$>40$ & 11 & $11,4 \%$ \\
\hline Total & 100 & $100 \%$ \\
\hline
\end{tabular}

Sumber: Data yang diolah 2020 
Berdasarkan tabel 4.2 Diketahui karakteristik responden berdasarkan usia yang paling mendominasi usia 30-40 responden dengan persentase $39.3 \%$. Dari data tersebut menyatakan bahwa Pada Konsumen Produk Smartphone Oppo pada Toko Jaya Ponsel Cabang Simpang Skip Kota Bengkulu yang paling banyak yaitu umur 30-40 karena diumur tersebut dalam mendirikan suatu usaha sudah memiliki pengalaman yang lebih banyak, dan usaha nya sudah lama berdiri.

\subsubsection{Karakteristik Responden Berdasarkan Pendidikan Terakhir}

Jumlah responden berdasarkan Pendidikan Terakhir yang ada Pada konsumen smartphone Oppo pada Toko Jaya Ponsel dapat dilihat pada tabel 4.3.

Tabel 4.3

Karakteristik Responden Berdasarkan Pendidikan Terakhir

\begin{tabular}{|l|l|l|l|}
\hline No & \multicolumn{1}{|c|}{ Pendidikan terakhir } & \multicolumn{1}{c|}{ Jumlah } & \multicolumn{1}{c|}{ Presentase } \\
\hline 1 & Dll & 17 orang & $19,1 \%$ \\
\hline 2 & SMA & 36 orang & $36,4 \%$ \\
\hline 3 & Diploma & 13 orang & $12,9 \%$ \\
\hline 4 & Sarjana & 34 orang & $33,6 \%$ \\
\hline & Total & $\mathbf{1 0 0}$ orang & $\mathbf{1 0 0 \%}$ \\
\hline
\end{tabular}

Sumber: Data yang diolah 2020

Berdasarkan tabel di atas diketahui karakteristik responden berdasarakan pendidikan terakhir, Dll sebanyak 17 orang atau 19,1\%, SMA sebanyak 36 orang atau 36,4\%, Diploma sebanyak 13 orang atau 12,9\% dan S1 sebanyak 34 orang atau 33,6\%, Dapat disimpulkan bahwa pada umumnya responden yang memiliki tingkat pendidikan terbanyak adalah Sarjana sebanyak 36 orang atau 36,4\%. Hal ini menunjukkan bahwa konsumen pada Toko Jaya Ponsel didominasi oleh SMA dan Sarjana. 


\subsubsection{Hasil Analisis dan Pengujian Instrumen}

Adapun uji instrumen yang dimaksud adalah menguji validitas dan reliabilitas yang dilakukan pada sampel khusus sejumlah 100 orang responden diluar sampel penelitian yaitu pedagang eceran yang belum menjadi responden penelitian. Pengujian instrumen pada sampel khusus dilakukan sebelum dilakukannya penelitian.

\subsubsection{Hasil Uji Validitas}

Pada uji validitas instrumen yang akan dilakukan pada setiap instrumen penelitian memperoleh hasil jika $\mathrm{r}$ positif, serta $\mathrm{r} \geq 0,30$ maka pernyataan tersebut valid, dan jika $r<0,30$ maka item pernyataan tidak valid (Sugiyono 2013). Dapat dilihat pada tabel 4.4 Dari setiap item pernyataan.

Tabel 4.4

Hasil Uji Validitas Instrumen

\begin{tabular}{|c|c|c|c|c|}
\hline \multirow{3}{*}{ Variabel } & $\begin{array}{c}\text { Item } \\
\text { Pernyataan }\end{array}$ & $\begin{array}{c}\text { Corrected Item } \\
\text { Pernyataan Total } \\
\text { Correlation }\end{array}$ & $\mathrm{R}$ & Keterangan \\
\hline \multirow{4}{*}{ Product Innovation } & 1 & .571 & 0.30 & Valid \\
\cline { 2 - 5 } & 2 & .531 & 0.30 & Valid \\
\cline { 2 - 5 } & 3 & .268 & 0.30 & Valid \\
\cline { 2 - 5 } & 4 & .662 & 0.30 & Valid \\
\cline { 2 - 5 } & 5 & .690 & 0.30 & Valid \\
\hline \multirow{3}{*}{ Brand Image } & 6 & .489 & 0.30 & Valid \\
\cline { 2 - 5 } & 1 & .713 & 0.30 & Valid \\
\cline { 2 - 5 } & 2 & .420 & 0.30 & Valid \\
\cline { 2 - 5 } & 3 & .498 & 0.30 & Valid \\
\cline { 2 - 5 } & 5 & .441 & 0.30 & Valid \\
\cline { 2 - 5 } & 5 & .672 & 0.30 & Valid \\
\hline & 5 & .553 & 0.30 & Valid \\
\hline
\end{tabular}




\begin{tabular}{|c|c|c|c|c|}
\hline \multirow{4}{*}{} & 1 & .629 & 0.30 & Valid \\
\cline { 2 - 5 } & 2 & .708 & 0.30 & Valid \\
\cline { 2 - 5 } & 3 & .500 & 0.30 & Valid \\
\cline { 2 - 5 } Keputusan & 4 & .512 & 0.30 & Valid \\
\cline { 2 - 5 } & 5 & .128 & 0.30 & Valid \\
\cline { 2 - 5 } & 6 & .460 & 0.30 & Valid \\
\cline { 2 - 5 } & 7 & .671 & 0.30 & Valid \\
\cline { 2 - 5 } & 8 & .409 & 0.30 & Valid \\
\hline
\end{tabular}

Sumber: Output SPSS 24.0

\subsubsection{Hasil Uji Reliabilitas}

Pada uji reliabilitas yang dilakukan terhadap setiap instrumen penelitian memperoleh hasil bahwa nilai Cronbach's Alpha pada setiap instrumen penelitian ini menunjukan nilai > 0,60 menunjukkan reliabel sempurna (Agus Tri Basuki dan Nano Prawoto 2016). Hal tersebut menunjukan bahwa semua instrumen penelitian ini reliabel sehingga dapat digunakan untuk melakukan penelitian. Berikut ini hasil dari uji reliabilitas dari penelitian ini.

Tabel 4.5

Hasil Uji Reliabilitas

\begin{tabular}{|c|l|c|c|c|}
\hline No & \multicolumn{1}{|c|}{ Variabel } & $\begin{array}{c}\text { Cronbach's } \\
\text { Alpha }\end{array}$ & r table & Keterangan \\
\hline 1 & Product Innovation & .809 & 0.60 & Reliabel \\
\hline 2 & Brand Image & .795 & 0.60 & Reliabel \\
\hline 3 & Keputusan Pembelian & .914 & 0.60 & Reliabel \\
\hline
\end{tabular}

Sumber: Output SPSS 24,0 


\subsubsection{Uji Asumsi Klasik}

\subsubsection{Uji Asumsi Klasik Normalitas}

Pada tabel test of normality dengan mengunakan kolmogorov-smirnov nilai sig $>0,05$, bisa dilihat bahwa data berdistribusi normal :

\section{Gambar 4.1}

\section{Grafik histrogram uji normalitas}

Product Innovation $\left(\mathrm{X}_{1}\right)$ dan Brand Image $\left(\mathrm{X}_{2}\right)$ terhadapa Keputusan Pembelian( $(\mathrm{Y})$

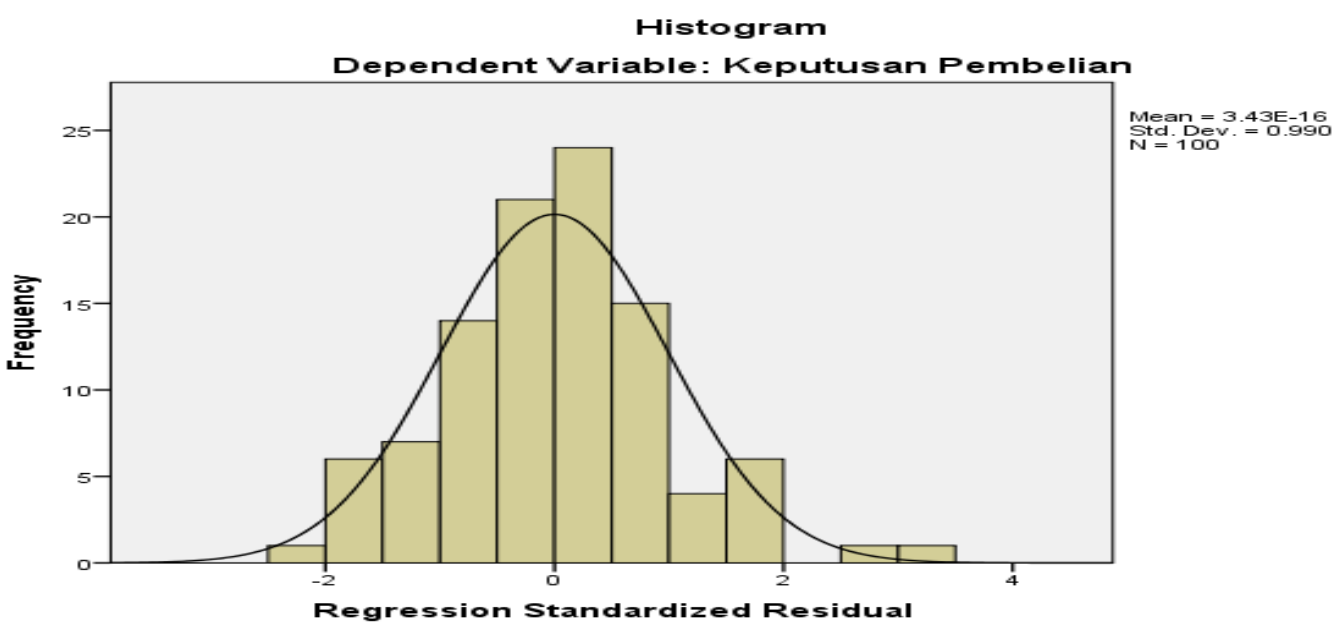

Gambar 4.2 dan 4.3

Histogram diatas menunjukan bahwa grafik uji nomarlitas mengambarkan penyebaran data disekitar garis diagonal dan penyebarannya mengikuti arah garis diagonal grafik tersebut, maka model regresi yang digunakan dalam penelitian ini memenuhi asumsi normalitas.

\subsubsection{Uji Asumsi Klasik Multikoleritas}

Uji multikolineritas ini bertujuan untuk mengetahui apakah tiap-tiap variabel bebas yaitu Product Innovationdan dan Brand Image, saling berhubungan secara linier. Pengujian adanya multikoleritas ini dapat dilakukan dengan melihat 
nilai tolenrasi diatas 0,1 dan vif nya lebih kecil dari 10 tidak ada kecendrungan terjadi gejala multikoliner. Pengujian multikolonieritas mengunakan software spss versi 2.4 dapat dilihat pada tabel dibawah ini :

\section{Tabel 4.6}

Uji multikolinieritas antara Product Innovation $\left(\mathrm{X}_{1}\right)$ dan Brand Image $\left(\mathrm{X}_{2}\right)$ dengan variabel Keputusan Pembelian (Y)

\begin{tabular}{|l|l|r|r|c|}
\hline No & \multicolumn{1}{|c|}{ Variabel } & Tolerance & \multicolumn{1}{c|}{ VIF } & Keterangan \\
\hline 1 & Product Innovation & .525 & 1.904 & Non Multikolinieritas \\
\hline 2 & Brand Image & .525 & 1.904 & Non Multikolinieritas \\
\hline
\end{tabular}

Sumber Penelitian 2020

Berdasarkan Tabel 4.8 diatas terlihat bahwa semua variabel mempunyai nilai toleransi diatas 0,1 dan nilai VIF dibawah 10 , dengan demikian dapat disimpulkan bahwa variabel pada penelitian ini bebas multikolinieritas.

\subsubsection{Uji Asumsi Klasik Heteroskesdastis}

Uji heterokedasitas bertujuan untuk menguji apakah dalam model regresi terjadi ketidak sama varians. Adapun hasil uji statistic heterokedasitas yang diperoleh dalam penelitian ini adalah sebagai berikut : 


\section{Gambar 4.2}

\section{Uji penyimpangan Heteroskedasitas}

\section{Antara Variabel - Variabel Product Innovation $\left(\mathrm{X}_{1}\right)$ dan Brand Image $\left(\mathrm{X}_{2}\right)$ terhadapa Keputusan Pembelian (Y)}

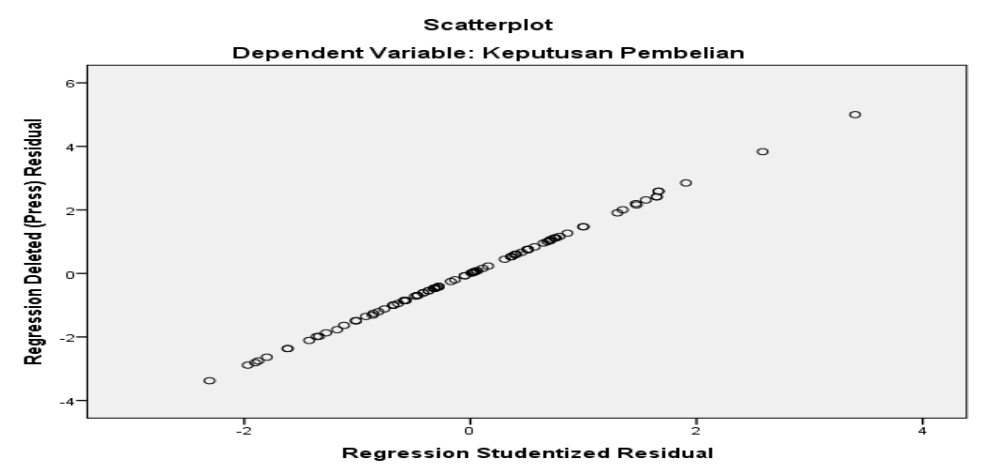

Grafik scatterplot yang ditampilkan untuk uji heterokesdastisitas menampakan titik-titik yang menyebar secara acak dan tidak ada pola yang jelas terbentuk serta dalam penyebaran titik-titik tersebut menyebar dibawah dan diatas angka 0 pada sumbu $\mathrm{Y}$. Hal tersebut mengindentifikasikan tidak terjadinya heterokesdastisitas pada model regresi, sehinga model regresi layak dipakai untuk memprediksi variabel Keputusan Pembelian (Y).

\subsubsection{Deskripsi Tanggapan Responden Terhadap Variabel Penelitian}

\subsubsection{Tanggapan Responden Terhadap Variabel Product Innovation}

$$
\left(\mathbf{X}_{1}\right)
$$

Pada variabel Product Innovation penilaian dilakukan dengan tiga Indikator, Adapun tanggapan responden terhadap variabel Product Innovation adalah sebagai berikut: 
Table 4.7

Tanggapan Responden

Terhadap Variabel Product Innovation $\left(\mathrm{X}_{1}\right)$

\begin{tabular}{|c|c|c|c|c|c|c|c|c|}
\hline \multirow{2}{*}{ No } & \multirow{2}{*}{ Pernyataan } & \multicolumn{5}{|c|}{ Penilaian } & \multirow{2}{*}{ Jumlah } & \multirow{2}{*}{ Rata-rata } \\
\hline & & STS & TS & $\mathrm{N}$ & $\mathrm{S}$ & SS & & \\
\hline 1 & $\begin{array}{l}\text { Produk Smartphone } \\
\text { OPPO mudah } \\
\text { diterima konsumen }\end{array}$ & 2 & 3 & 44 & 41 & 10 & 354 & 3.54 \\
\hline 2 & $\begin{array}{l}\text { Produk Smartphone } \\
\text { OPPO mudah } \\
\text { ditemukan dipasaran }\end{array}$ & & 1 & 31 & 52 & 16 & 383 & 3.83 \\
\hline 3 & $\begin{array}{l}\text { Perusahaan } \\
\text { Smartphone OPPO } \\
\text { mampu } \\
\text { memodifikasi } \\
\text { produknya sehingga } \\
\text { tampak semakin } \\
\text { canggih dan menarik }\end{array}$ & & 2 & 48 & 37 & 13 & 361 & 3.61 \\
\hline 4 & $\begin{array}{l}\text { Perusahaan } \\
\text { Smartphone OPPO } \\
\text { mampu } \\
\text { memodifikasi } \\
\text { produknya sehingga } \\
\text { membuat } \\
\text { penggunanya lebih } \\
\text { nayaman }\end{array}$ & & 5 & 35 & 44 & 16 & 371 & 3.71 \\
\hline 5 & $\begin{array}{l}\text { Produk Smartphone } \\
\text { OPPO mampu } \\
\text { menghasilkan video } \\
\text { dengan kualitas yang } \\
\text { sangat baik seperti } \\
\text { terdapat pada } \\
\text { Smartphone OPPO } \\
\text { Reno2 }\end{array}$ & & 3 & 38 & 37 & 22 & 378 & 3.78 \\
\hline 6 & $\begin{array}{l}\text { Produk Smartphone } \\
O P P O \text { semakin } \\
\text { berinovasi dengan } \\
\text { menghadirkan dua } \\
\text { speaker yang berfitur } \\
\text { Dolby Atmos }\end{array}$ & & 1 & 30 & 50 & 19 & 387 & 3.87 \\
\hline Rat & rata & & & & & & & 3.72 \\
\hline
\end{tabular}

Sumber: Data yang diolah 2020 
Adapun hasil analisis penilaian responden pada tabel 4.6 Terhadap variabel Product Innovation $\left(\mathrm{X}_{1}\right)$ memiliki nilai rata-rata tertinggi yaitu 3.87 dan indikator informasi pasar memiliki rata-rata terendah yaitu 3.54. Variabel Product Innovation menghasilkan nilai rata-rata sebesar 3.72. Menunjukan bahwa rata-rata pernyataan penilaian responden mengenai variabel Product Innovation adalah pada kategori baik.

\subsubsection{Tanggapan Responden Terhadap Variabel Brand Image $\left(\mathrm{X}_{2}\right)$}

Pada variabel Brand Image $\left(\mathrm{X}_{2}\right)$ penilaian dilakukan dengan tiga Indikator, Adapun tanggapan responden terhadap variabel Brand Image adalah sebagai berikut :

Table 4.8

Tanggapan Responden Terhadap Variabel Brand Image $\left(\mathrm{X}_{2}\right)$

\begin{tabular}{|c|c|c|c|c|c|c|c|c|}
\hline \multirow[t]{2}{*}{ No } & \multirow[t]{2}{*}{ Pernyataan } & \multicolumn{5}{|c|}{ Peniliaian } & \multirow{2}{*}{ Jumlah } & \multirow{2}{*}{$\begin{array}{l}\text { Rata- } \\
\text { rata }\end{array}$} \\
\hline & & STS & $\mathrm{TS}$ & $\mathrm{N}$ & $\mathrm{S}$ & SS & & \\
\hline 1 & $\begin{array}{l}\text { Smartphone OPPO } \\
\text { merupakan produksi } \\
\text { perusahaan yang } \\
\text { terkenal }\end{array}$ & & 3 & 38 & 38 & 21 & 377 & 3.77 \\
\hline 2 & $\begin{array}{l}\text { Produk smartphone } \\
O P P O \text { adalah } \\
\text { produk yang } \\
\text { dikembangkan di } \\
\text { pabrik yang } \\
\text { berteknologi tinggi }\end{array}$ & & 3 & 29 & 50 & 18 & 383 & 3.83 \\
\hline 3 & $\begin{array}{l}\text { Smartphone OPPO } \\
\text { memiliki tampilan } \\
\text { fisik yang menarik }\end{array}$ & & & 23 & 50 & 27 & 404 & 4.04 \\
\hline 4 & $\begin{array}{l}\text { Produk smartphone } \\
O P P O \text { mempunyai } \\
\text { banyak varian } \\
\text { produk }\end{array}$ & 2 & 3 & 37 & 35 & 23 & 374 & 3.74 \\
\hline 5 & $\begin{array}{l}\text { Smartphone OPPO } \\
\text { adalah produk yang }\end{array}$ & & 4 & 36 & 37 & 23 & 379 & 3.79 \\
\hline
\end{tabular}




\begin{tabular}{|l|l|l|l|l|l|l|l|l|}
\hline & mudah diucapkan & & & & & & & \\
\hline 6 & $\begin{array}{l}\text { Smartphone OPPO } \\
\text { adalah produk yang } \\
\text { telah dikenal oleh } \\
\text { banyak orang }\end{array}$ & 2 & 3 & 44 & 42 & 9 & 353 & 3.53 \\
\hline
\end{tabular}

Sumber: Data yang diolah 2020

Adapun hasil analisis penilaian responden pada tabel 4.7 Terhadap variabel Brand Image $\left(\mathrm{X}_{2}\right)$ (Brand Image dilakukan secara langsung kepada konsumen sehingga konsumen benar-benar mengetahui pelayanan yang lebih baik) dengan rata-rata tertinggi yaitu 4.04 dan indikator Brand Image memiliki rata-rata terendah yaitu 3,53. Variabel Brand Image menghasilkan nilai rata-rata sebesar 3.78. Menunjukan bahwa rata-rata pernyataan penilaian responden mengenai variabel Brand Image adalah pada kategori baik.

\subsubsection{Tanggapan Responden Terhadap Variabel Keputusan Pembelian}

$(\mathbf{Y})$

Pada variabel Keputusan Pembelian penilaian dilakukan dengan empat indikator. Adapun tanggapan responden terhadap variabel Keputusan Pembelian adalah sebagai berikut:

Table 4.9

Tanggapan Responden

Terhadap Variabel Keputusan Pembelian (Y)

\begin{tabular}{|l|l|l|l|l|l|l|l|l|}
\hline \multirow{2}{*}{ No } & \multicolumn{1}{|c|}{ Pernyataan } & \multicolumn{5}{|c|}{ Peniliaian } & \multicolumn{2}{|c|}{$\begin{array}{c}\text { Rata- } \\
\text { rata }\end{array}$} \\
\hline 1 & $\begin{array}{l}\text { Saya mantap dan } \\
\text { percaya terhadap } \\
\text { produk Smartphone } \\
\text { OPPO }\end{array}$ & & 4 & 35 & 45 & 16 & 373 & 3.73 \\
\hline 2 & $\begin{array}{l}\text { Saya meyakini } \\
\text { bahwa kualitas } \\
\text { produk Smartphone }\end{array}$ & & 2 & 38 & 39 & 21 & 379 & 3.79 \\
\hline
\end{tabular}




\begin{tabular}{|c|c|c|c|c|c|c|c|}
\hline & $O P P O$ telah teruji & & & & & & \\
\hline 3 & $\begin{array}{l}\text { Saya memiliki } \\
\text { ketertarikan dalam } \\
\text { membeli produk } \\
\text { Smartphone OPPO } \\
\text { (dilihat dari kualitas, } \\
\text { design dan fiturnya) }\end{array}$ & & 31 & 51 & 18 & 387 & 3.87 \\
\hline 4 & $\begin{array}{l}\text { Saya biasa membeli } \\
\text { produk } O P P O \\
\text { karena kualitasnya }\end{array}$ & 1 & 29 & 52 & 18 & 387 & 3.87 \\
\hline 5 & $\begin{array}{l}\text { Saya akan } \\
\text { menyarankan } \\
\text { keluarga dan saudara } \\
\text { untuk membeli dan } \\
\text { menggunakan } \\
\text { produk Smartphone } \\
\text { OPPO }\end{array}$ & 6 & 32 & 51 & 11 & 367 & 3.67 \\
\hline 6 & $\begin{array}{l}\text { Saya akan } \\
\text { menyarankan pada } \\
\text { teman untuk } \\
\text { membeli dan } \\
\text { menggunakan } \\
\text { produk Smartphone } \\
\text { OPPO }\end{array}$ & 1 & 23 & 49 & 27 & 402 & 4.02 \\
\hline 7 & $\begin{array}{l}\text { Adanya kepuasan } \\
\text { yang dirasakan } \\
\text { setelah membeli dan } \\
\text { menggunakan } \\
\text { Smartphone OPPO }\end{array}$ & 5 & 39 & 32 & 24 & 375 & 3.75 \\
\hline 8 & $\begin{array}{l}\text { Apabila perusahaan } \\
O P P O \\
\text { mengeluarkan } \\
\text { produk jenis baru } \\
\text { saya akan } \\
\text { melakukan } \\
\text { pembelian lagi }\end{array}$ & 3 & 28 & 51 & 18 & 384 & 3.84 \\
\hline \multicolumn{7}{|c|}{ Rata-rata } & 3,8 \\
\hline
\end{tabular}

Sumber: Data yang diolah 2020

Adapun hasil analisis penilaian responden pada tabel 4.8 Terhadap variabel

Keputusan Pembelian (Y) (perusahaan dalam satu tahun ini selalu mengalami peningkatan penjualan, setelah melakukan pengembangan Keputusan Pembelian) 
memiliki rata-rata tertinggi yaitu 4.02, dan memiliki rata-rata terendah yaitu 3.67. Dengan variabel keputusan pembelian menghasilkan nilai rata-rata sebesar 3.82. Menunjukan bahwa rata-rata pernyataan penilaian responden mengenai variabel Keputusan Pembelian adalah pada kategori baik.

\subsection{Hasil Penelitian}

\subsubsection{Analisis Regresi Linear Berganda}

Analisis regresi linear berganda yang akan dibahas dalam penelitian ini sehingga penulis bisa menggambarkan mengenai tanggapan responden (Product Innovation dan Brand Image) terhadap Keputusan Pembelian pada Pada Konsumen Produk Smartphone Oppo pada Jaya Ponsel Cabang Simpang Skip Kota Bengkulu. Berdasarkan estemasi regresi linier berganda dengan menggunakan program SPSS Versi 24,0 For Windows,maka diperoleh tabel dibawah ini :

Tabel 4.10

Hasil Analisis Regresi Linear Berganda

\begin{tabular}{|c|c|c|c|c|c|c|}
\hline \multicolumn{7}{|c|}{ Coefficients $^{a}$} \\
\hline \multirow{2}{*}{\multicolumn{2}{|c|}{ Model }} & \multicolumn{2}{|c|}{$\begin{array}{l}\text { Unstandardized } \\
\text { Coefficients }\end{array}$} & \multirow{2}{*}{$\begin{array}{c}\text { Standardized } \\
\text { Coefficients } \\
\text { Beta }\end{array}$} & \multirow[b]{2}{*}{$\mathbf{t}$} & \multirow[b]{2}{*}{ Sig. } \\
\hline & & B & Std. Error & & & \\
\hline \multirow[t]{3}{*}{1} & (Constant) & 4.891 & 1.161 & & 4.212 & .000 \\
\hline & Product Innovation & .633 & .067 & .533 & 9.417 & .000 \\
\hline & Brand Image & .507 & .062 & .461 & 8.146 & .000 \\
\hline
\end{tabular}

a. Dependent Variable: Keputusan Pembelian

Sumber: Output SPSS 24,0 
Dari perhitungan hasil diatas didapatkan persamaan regresinya adalah sebagai berikut :

$$
\mathrm{Y}=4.891+0.633\left(\mathrm{X}_{1}\right)+0.507\left(\mathrm{X}_{2}\right)
$$

Berdasarkan persamaan regresi diatas, maka dapat dijelaskan sebagai berikut :

1. Nilai Konstanta 4.891 mempunyai arti bahwa apabila variabel Product Innovation $\left(\mathrm{X}_{1}\right)$, Brand Image $\left(\mathrm{X}_{2}\right)$ terhadap Keputusan Pembelian $(\mathrm{Y})$ sama dengan nol, maka variabel Keputusan Pembelian akan tetap yaitu 4.891 apabila variabel Product Innovation $\left(\mathrm{X}_{1}\right)$ dan Brand Image $\left(\mathrm{X}_{2}\right)$ sama dengan nol.

2. Koefisien Regresi $X_{1}$, sebesar 0.633 mempunyai makna jika nilai variabel Product Innovation $\left(\mathrm{X}_{1}\right)$ naik satu satuan maka nilai Keputusan Pembelian (Y) akan naik sebesar 0.633 dengan asumsi variabel Brand Image $\left(\mathrm{X}_{2}\right)$ dianggap tetap.

3. Koefisien Regresi $X_{2}$, sebesar 0.507 mempunyai makna jika nilai variabel Brand Image $\left(\mathrm{X}_{2}\right)$ naik satu satuan maka nilai variabel Keputusan Pembelian (Y) akan naik sebesar 0.507 dengan asumsi variabel Product Innovation $\left(\mathrm{X}_{1}\right)$ dianggap tetap.

4. Hasil penelitian dalam penelitian yang paling dominan mempengaruhi variable Keputusan Pembelian (Y) adalah Variabel Product Innovation $\left(\mathrm{X}_{1}\right)$ adalah sebesar 0.633 dan Variabel Brand Image $\left(\mathrm{X}_{2}\right)$ adalah sebesar 0.507. 


\subsubsection{Koefisisen Determinasi $\left(\mathbf{R}^{2}\right)$}

Untuk mengetahui besarnya presentase sumbangan pengaruh variabel bebas Product Innovation $\left(\mathrm{X}_{1}\right)$ dan Brand Image $\left(\mathrm{X}_{2}\right)$ terhadap variabel terikat Keputusan Pembelian (Y) maka dari perhitungan komputer menggunakan SPSS 24,0 didapatkan uji koefisien determinasi dapat dilihat pada table sebagai berikut:

Tabel 4.14

Nilai Koefisien Determinasi $\left(\mathrm{R}^{2}\right)$

\begin{tabular}{|l|r|r|r|r|}
\hline \multicolumn{5}{|c|}{ Model Summary $^{\mathrm{b}}$} \\
\hline Model & $\mathrm{R}$ & R Square & Adjusted R Square & Std. Error of the Estimate \\
\hline 1 & $.915^{\mathrm{a}}$ & .837 & .833 & $\mathbf{1 . 4 5 5 1 5}$ \\
\hline
\end{tabular}

Sumber: Output SPSS 24,0 (lampiran 5)

Berdasarkan tabel diatas dapat diketahui nilai koefisien determinasi Adjusted $\left(\mathrm{R}^{2}\right)$ diperoleh nilai sebesar 0.837 . Nilai ini mempunyai arti bahwa variabel Product Innovation dan Brand Image terhadap variabel Keputusan Pembelian memberikan sumbangan sebesar 0.837 atau $83.7 \%$ terhadap Keputusan Pembelian pada Pada Konsumen Produk Smartphone Oppo pada Jaya Ponsel Cabang Simpang Skip Kota Bengkulu sedangkan sisanya sebesar 0.163 atau $16.3 \%$ dipengaruhi oleh variabel lain yang tidak masuk dalam model penelitian ini. 


\subsubsection{Pengujian Hipotesis Dengan Uji t}

Untuk menguji pengaruh variabel bebas secara parsial terhadap variabel terikat digunakan uji t dapat dilihat pada table sebagai berikut :

Tabel 4.15

Hasil Pengujian Hipotesis dengan Uji t

\begin{tabular}{|c|c|c|c|c|c|c|}
\hline \multicolumn{7}{|c|}{ Coefficients $^{a}$} \\
\hline & & \multicolumn{2}{|c|}{$\begin{array}{l}\text { Unstandardized } \\
\text { Coefficients }\end{array}$} & \multirow{2}{*}{$\begin{array}{c}\begin{array}{c}\text { Standardized } \\
\text { Coefficients }\end{array} \\
\text { Beta }\end{array}$} & \multirow[b]{2}{*}{$\mathbf{T}$} & \multirow[b]{2}{*}{ Sig. } \\
\hline \multicolumn{2}{|c|}{ Model } & B & Std. Error & & & \\
\hline \multirow[t]{3}{*}{1} & (Constant) & 4.891 & 1.161 & & 4.212 & .000 \\
\hline & Product Innovation & .633 & .067 & .533 & 9.417 & .000 \\
\hline & Brand Image & .507 & .062 & .461 & 8.146 & .000 \\
\hline & dent Variable: Kep & & & & & \\
\hline
\end{tabular}

Sumber: Output SPSS 24.0 (lampiran 5)

Melalui perhitungan yang dilakukan dengan menggunakan program SPSS, maka perbandingan antara $t_{\text {hit }}$ dengan $t_{a / 2}(n-k-1)=100-2-1=97(1.984)$ setiap variabel sebagai berikut :

1. Product Innovation yaitu $\mathrm{t}_{\mathrm{hit}}>\mathrm{t}_{\alpha / 2}(9.417>1.984)$ dan (sig $\alpha=0,000<$ 0,050), hal tersebut menyatakan bahwa adanya pengaruh yang signifikan Product Innovation $\left(\mathrm{X}_{1}\right)$ terhadap Keputusan Pembelian pada Pada Konsumen Produk Smartphone Oppo pada Jaya Ponsel Cabang Simpang Skip Kota Bengkulu.

2. Berdasarkan uji $t_{\text {hit }}$ untuk variabel Brand Image $\left(\mathrm{X}_{2}\right)$ yaitu $t_{\text {hit }}>t_{\alpha / 2}(8.146$ $>1.984)$ dan $(\operatorname{sig} \alpha=0,000<0,050)$, hal tersebut menyatakan bahwa adanya pengaruh yang signifikan Brand Image terhadap Keputusan Pembelian pada 
Pada Konsumen Produk Smartphone Oppo pada Jaya Ponsel Cabang Simpang Skip Kota Bengkulu.

3. Dari hasil penelitian variable yang dominan adalah Variabel Product Innovation $\left(\mathrm{X}_{1}\right)$ sebesar 9.417 dan variable Brand Image $\left(\mathrm{X}_{2}\right)$ sebesar 8.146.

\subsubsection{Pengujian Hipotesis Dengan Uji F}

SSSUntuk menguji pengaruhh variabel bebas secara parsial terhadap variabel terikat digunakan uji F sebagai berikut :

Tabel 4.16

Hasil Pengujian Hipotesis dengan Uji F

\begin{tabular}{|c|c|c|c|c|c|c|}
\hline \multicolumn{7}{|c|}{ ANOVA $^{a}$} \\
\hline \multicolumn{2}{|c|}{ Model } & Sum of Squares & Df & Mean Square & $\mathbf{F}$ & Sig. \\
\hline \multirow[t]{3}{*}{1} & Regression & 1051.447 & 2 & 525.724 & 248.282 & $.000^{b}$ \\
\hline & Residual & 205.393 & 97 & 2.117 & & \\
\hline & Total & 1256.840 & 99 & & & \\
\hline \multicolumn{7}{|c|}{ a. Dependent Variable: Keputusan Pembelian } \\
\hline
\end{tabular}

Sumber: Output SPSS 24,0

Berdasarkan tabel uji hipotesis dengan uji $\mathrm{F}$ diatas diperoleh $\mathrm{F}_{\text {hitung }}$ sebesar 248.282 dengan nilai $\mathrm{F}_{\text {tabel }}$ sebesar 3.936 yaitu $(248.282>3.936)$ dan $(\operatorname{sig} \alpha=$ $0.000<0,050)$, maka dengan demikian dapat disimpulkan bahwa $\mathrm{H}_{3}$ diterima artinya secara simultan variabel Product Innovation $\left(\mathrm{X}_{1}\right)$ dan Brand Image $\left(\mathrm{X}_{2}\right)$ berpengaruh yang signifikan terhadap Keputusan Pembelian (Y) Pada Konsumen Produk Smartphone Oppo di Toko Jaya Ponsel Cabang Simpang Skip Kota Bengkulu. 


\subsubsection{Pembahasan Hasil Penelitian}

\subsubsection{Keputusan Pembelian Produk Smartphone OPPO di Toko Jaya Ponsel Simpang SKIP Kota Bengkulu}

Hasil penelitian ini menunjukan bahwa Keputusan Pembelian Smartphone Oppo sudah dikatakan baik. Hal ini dapat dilihat dari meningkatnya minat beli kosumen produk smartphone oppo sehingga sales marketing mampu mencapai target pejualan yang telah ditetapkan dibandingkan dengan sebelumnya. Kemudian dapat juga dilihat dari tanggapan responden, variabel Keputusan Pembelian (Y) berada pada kategori baik dengan nilai tertinggi yaitu 4,02 dan memiliki nilai rata-rata terendah yaitu 3,62. Maksudnya adalah keputusan pembelian pada konsumen smartphone oppo di Toko Jaya ponsel cabang Skip Kota Bengkulu sudah baik. Dilihat dari pernyataan nomor 6 (Saya akan menyarankan pada teman untuk membeli dan menggunakan produk Smartphone $O P P O$ ) dan pernyataan nomor 5 (Saya akan menyarankan keluarga dan saudara untuk membeli dan menggunakan produk Smartphone OPPO ) artinya bahwa rata-rata konsumen menyarankan kepada orang terdekatnya untuk membeli produk smartphone oppo.

\subsubsection{Product Innovation Produk Smartphone OPPO di Toko Jaya Ponsel Simpang SKIP Kota Bengkulu}

Hasil penelitian menunjukan bahwa Product Innovation Smartphone Oppo sudah dikatakan baik. Hal ini dapat dilihat pada produk smartphone Oppo di Toko Jaya Ponsel Cabang SKIP Kota Bengkulu yang memberikan banyak kemudahan dengan fitur-fitur yang canggih dan menarik sehingga membuat konsumennya 
merasa nyaman. Sehingga meningkatnya minat beli konsumen pada produk smartphone oppo di Toko Jaya Ponsel. Kemudian dilihat dari tanggapan responden, variabel Product Innovation $\left(\mathrm{X}_{1}\right)$ dengan nilai tertinggi 3,87 dan nilai terendah yaitu 3,54 dilihat dari pernyataan nomor 2 (Produk Smartphone $O P P O$ semakin berinovasi dengan menghadirkan dua speaker yang berfitur Dolby Atmos) dan pernyataan nomor 1 (Produk Smartphone OPPO mudah diterima konsumen ) maksudnya adalah produk smartphone oppo mudah diterima oleh konsumen karena selalu berinovasi dalam setiap designnya.

\subsubsection{Brand Image Produk Smartphone OPPO di Toko Jaya Ponsel Simpang SKIP Kota Bengkulu}

Hasil penelitian ini menunjukan bahwa brand image pada produk smartphone oppo di Toko Jaya Ponsel Cabang Skip Kota Bengkulu sudah dikatakan baik. Hal ini disebabkan oleh brand dari produk smartphone oppo sudah banyak dikenal dikalangan masyarakat karena kualitas dari produknya dan mudah ditemukan dipasaran. Dilihat dari hasil tanggapan responden, variabel Brand Image $\left(\mathrm{X}_{2}\right)$ dengan nilai tertinggi 4,04 dan nilai terendah yaitu 3,53. Dilihat dari pernyataan nomor 3 (Smartphone $O P P O$ memiliki tampilan fisik yang menarik) dan pernyataan nomor 6 (Smartphone OPPO adalah produk yang telah dikenal oleh banyak orang), maksudnya adalah produk smartphone oppo selalu menghadirkan design yang menarik dan membuat pemakai nyaman menggunakannya serta memiliki brand yang baik sehingga mampu dikenal oleh banyak orang. 


\subsubsection{Pengaruh Product Innovation $\left(\mathrm{X}_{1}\right)$ Terhadap Keputusan Pembelian}

$(\mathbf{Y})$

Berdasarkan hasil penelitian dan pengolahan data yang dilakukan pada Konsumen Toko Jaya ponsel Cabang SKIP Kota Bengkulu melalui penyebaran kuesioner terhadap 100 orang responden yang telah diuji sehingga dapat diketahui pengaruh Product innovation Terhadap Keputusan Pembelian Produk Smartphone $O P P O$ di Toko Jaya Ponsel Cabang Skip Kota Bengkulu.

Dari analisis regresi linier berganda diperoleh persamaan $\mathrm{Y}=4.891+0.633$ $\left(\mathrm{X}_{1}\right)+$ angka ini mempunyai makna nilai konstanta 4.891 mempunyai arti variable Product Innovation $\left(\mathrm{X}_{1}\right)$ Keputusan Pembelian $(\mathrm{Y})$ pada konsumen smartphone oppo di Toko Jaya Ponsel Cabang Skip Kota Bengkulu naik satu, maka nilai Keputusan Pembelian (Y) akan naik sebesar 0.633 dengan asumsi variabel Brand Image $\left(\mathrm{X}_{2}\right)$ dianggap tetap. hal ini berlaku saat dilaksanakn penelitian. Koefisien regresi variable Product Innovation $\left(\mathrm{X}_{1}\right)$ sebesar 0,633 dan mempunyai makna bahwa apabila Product Innovation $\left(\mathrm{X}_{1}\right)$ ditingkatkan, maka akan meningkatkan keputusan pembelian (Y) pada konsumen produk smartphone oppo di Toko Jaya Ponsel Cabang Skip Kota Bengkulu.

Product Innovation memiliki pengaruh terhadap keputusan pembelian. Hal ini terlihat pada uji t yang menyatakan memiliki nilai $t_{h i t}>t_{\alpha / 2} 9.417>1.984$ ) dan ( $\operatorname{sig} \alpha=0,000<0,050$ ), maka dari penelitian yang dilakukan dalam penelitian terdahulu menyatakan bahwa Product Innovation memiliki pengaruh positif dan signifikan terhadap Keputusan Pembelian. 
Hasil penelitian ini sejalan dengan penelitian yang dilakukan oleh Ellisabet Tambunan, Marupa Siregar (2018) dengan judul "Pengaruh Promosi dan Inovasi produk terhadap Keputusan pembelian Batik Azzahra Medan”, menyatakan bahwa Inovasi Produk $\left(\mathrm{X}_{2}\right)$ Berpengaruh Positif Terhadap keputusan pembelian (Y).

Hasil penelitian juga sejalan dengan penelitian Candra Dery Bagus, dkk dengan judul "Pengaruh inovasi produk dan brand image terhadap keputusan pembelian pada olivia cake" menunjukkan bahwa Inovasi produk ( $\left.\mathrm{X}_{1}\right)$ berpengaruh positif dan signifikan terhadap Keputusan Pembelian (Y).

Hasil penelitian ini juga sejalan dengan penelitian Rasyid, Tri Indah (2018 ) dengan judul " Pengaruh inovasi produk dan harga terhadap keputusan pembelian sepeda motor dikota Tangerang Selatan", menunjukkan bahwa inovasi produk $\left(\mathrm{X}_{1}\right)$ berpengaruh positif dan signifikan terhadap Keputusan Pembelian (Y).

\subsubsection{Pengaruh Brand Image $\left(\mathrm{X}_{2}\right)$ Terhadap Keputusan Pembelian (Y)}

Berdasarkan hasil penelitian dan pengolahan data yang dilakukan pada Konsumen di Toko Jaya ponsel Cabang SKIP Kota Bengkulu melalui penyebaran kuesioner terhadap 100 orang responden yang telah diuji sehingga dapat diketahui pengaruh Brand Image Terhadap Keputusan Pembelian Produk Smartphone $O P P O$ di Toko Jaya Ponsel Cabang Skip Kota Bengkulu.

Dari analisis regresi linier berganda diperoleh persamaan $\mathrm{Y}=4.891+0.507$ $\left(\mathrm{X}_{2}\right)+$ angka ini mempunyai makna nilai konstanta 4.891 mempunyai makna jika nilai variabel Brand Image $\left(\mathrm{X}_{2}\right)$ naik satu satuan maka nilai variabel Keputusan 
Pembelian (Y) akan naik sebesar 0.507 dengan asumsi variabel Product Innovation $\left(\mathrm{X}_{1}\right)$ dianggap tetap, maka variable keputusan pembelian akan tetap yaitu, 4.891 hal ini berlaku saat dilaksanakn penelitian. Koefisien regresi variable Brand Image $\left(\mathrm{X}_{2}\right)$ sebesar 0,507 dan mempunyai makna bahwa apabila Brand Image $\left(\mathrm{X}_{2}\right)$ ditingkatkan, maka akan meningkatkan keputusan pembelian $(\mathrm{Y})$ pada konsumen produk smartphone oppo di Toko Jaya Ponsel Cabang Skip Kota Bengkulu.

Brand Image memiliki pengaruh terhadap keputusan pembelian. hal ini dibuktikan dengan hasil uji t menunjukan nilai $t_{h i t}>t_{\alpha / 2}(8.146>1.984)$ dan $(\operatorname{sig} \alpha$ $=0,002<0,050)$, maka dari penelitian yang dilakukan dalam penelitian terdahulu menyatakan bahwa Brand Image memiliki pengaruh positif dan signifikan terhadap Keputusan Pembelian.

Hasil penelitian ini sejalan dengan penelitian yang dilakukan oleh Gifani Auliannisa, Syahputra (2017) dengan judul "Pengaruh Citra Merek terhadap keputusan pemebelian produk smartphone oppo pada mahasiswa universitas Telkom", menyatakan bahwa Brand Image $\left(\mathrm{X}_{1}\right)$ Berpengaruh Positif Terhadap keputusan pembelian (Y).

Hasil Penelitian Ini Sejalan Dengan Penelitian Yang Dilakukan Oleh Dwi ajeng wulandari, Farah Oktafani (2017) dengan judul "Pengaruh Brand image terhadap proses keputusan pembelian sepatu Nike pada mahasiswa komunkikasi dan bisnis Telkom University Bandung", menyatakan bahwa Brand Image $\left(\mathrm{X}_{1}\right)$ Berpengaruh Positif Terhadap keputusan pembelian (Y). 
Hasil Penelitian Ini Sejalan Dengan Penelitian Yang Dilakukan Oleh Suhaily Lily dan Syarief Darmoyo (2017) dengan judul "Pengaruh Kualitas Produk, Harga Persepsi Dan Citra Merek Terhadap Keputusan Pembelian Diperoleh Kepercayaan Pelanggan (Studi Pada Produk Elektronik Merek Jepang) ", menyatakan bahwa Brand Image (X3) Berpengaruh Positif Terhadap keputusan pembelian (Y).

\subsubsection{Pengaruh Product Innovation dan Brand Image Terhadap Keputusan Pembelian Produk Smartphone Oppo}

Berdasarkan hasil penelitian dan pengolahan data yang dilakukan pada konsumen produk smartphone oppo di Toko Jaya Ponsel Cabang Skip Kota Bengkulu melalui penyebaran kuesioner terhadap 100 orang responden yang telah diuji sehingga dapat diketahui pengaruh Product Innovation dan Brand Image Terhadap Keputusan Pembelian Produk Smartphone OPPO DI Toko Jaya Ponsel Cabang Skip Kota Bengkulu.

Product Innovation $\left(\mathrm{X}_{1}\right)$ dan Brand Image $\left(\mathrm{X}_{2}\right)$ memiliki pengaruh terhadap Keputusan Pembelian (Y), hal ini terlihat pada uji F yang menyatakan dengan nilai $\mathrm{F}_{\text {tabel }}$ sebesar 3.936 yaitu $(248.282>3.936)$ dan $(\operatorname{sig} \alpha=0.000<0,050)$, maka dengan demikian dapat disimpulkan bahwa $\mathrm{H}_{3}$ diterima artinya secara simultan variabel Product Innovation $\left(\mathrm{X}_{1}\right)$ dan Brand Image $\left(\mathrm{X}_{2}\right)$ berpengaruh yang signifikan terhadap Keputusan Pembelian (Y) Pada Konsumen Produk Smartphone Oppo di Toko Jaya Ponsel Cabang Simpang Skip Kota Bengkulu.

Hasil penelitian juga sejalan dengan penelitian Candra Dery Bagus, dkk dengan judul "Pengaruh inovasi produk dan brand image terhadap keputusan 
pembelian pada olivia cake" menunjukkan bahwa Inovasi produk berpengaruh positif dan signifikan terhadap Keputusan Pembelian.

\section{BAB V}

\section{KESIMPULAN DAN SARAN}

\subsection{Kesimpulan}

Berdasarkan hasil penelitian yang telah dilakukan tentang pengaruh Product Innovation dan Brand Image Terhadap Keputusan Pembelian pada Konsumen Produk Smartphone Oppo pada Toko Jaya Ponsel Cabang Simpang Skip Kota Bengkulu, dapat disimpulkan sebagai berikut :

1. Product Innovation berpengaruh signifikan terhadap Keputusan Pembelian pada Konsumen Produk Smartphone Oppo pada Toko Jaya Ponsel Cabang Simpang Skip Kota Bengkulu.

2. Brand Image berpengaruh signifikan terhadap Keputusan Pembelian pada Konsumen Produk Smartphone Oppo pada Toko Jaya Ponsel Cabang Simpang Skip Kota Bengkulu.

3. Product Innovation $\left(\mathrm{X}_{1}\right)$ dan Brand Image $\left(\mathrm{X}_{2}\right)$ memilki pengaruhsignifikan terhadap Keputusan Pembelian (Y).

\subsection{Saran}

Berdasarkan hasil penelitian, pembahasan dan kesimpulan yang diperoleh, maka saran yang dapat diberikan sebagai berikut :

1. Hasil penelitian menunjukan adanya pengaruh yang signifikan antara variabel Product Innovation $\left(\mathrm{X}_{1}\right)$ dan Brand Image $\left(\mathrm{X}_{2}\right)$ terhadap Keputusan 
Pembelian (Y) Pada Pada Konsumen Produk Smartphone Oppo pada Toko Jaya Ponsel Cabang Simpang Skip Kota Bengkulu, variabel Product Innovation memiliki rata-rata terendah yaitu 3.67. Disarankan untuk lebih baiknya perlu ditingkatkan lagi Product Innovation, seperti perbanyak variasi produk, kualitas produk yang lebih baik agar dapat meningkatkan Keputusan Pembelian pada Konsumen Produk Smartphone Oppo pada Toko Jaya Ponsel Cabang Simpang Skip Kota Bengkulu.

2. Hasil penelitian terlihat bahwa pada variabel Brand Image memiliki tanggapan responden yang terendah yaitu 3.53 dikarenakan pengusaha kurang memperhatikan apa yang dibutuhkan oleh pelanggan dalam menawarkan produk yang tersedia. Disarankan sebaiknya para pemilik dapat lebih aktif dalam mencari dan memahami apa yang diinginkan oleh konsumen agar dapat meningkatkan Keputusan Pembelian yang lebih efektif.

3. Hasil penelitian terlihat bahwa pada variabel Product Innovation, dan Brand Image memiliki tanggapan responden yang terendah yaitu 3,54 dikarenakan para pengusaha kurang melakukan kegiatan-kegiatan yang dapat merangsang minat Konsumen seperti melakukan kegiatan yang mendukung kinerja pemasaran yang ada didalam perusahaan terutama Product Innovation, kualitas produk serta pelayanan yang lebih memuaskan. Disarankan pengusaha dapat memperkenalkan program kerja dan pola kelengkapan kerja dengan melakukan pengamatan secara rutin. 
4. Disarankan bagi peneliti selanjutnya khususnya penelitian yang sama perlu dipertimbangkan untuk faktor-faktor lain diluar variabel Product Innovation dan Brand Image tershadap Keputusan Pembelian serta dapat meningkatkan penjualan pada perusahaan sehingga akan menghasilkan penjualan lebih meningkat serta menjadi suatu referensi bagi penelitian selanjutnya yang lebih baik.

\section{Daftar Pustaka}

Anjani, R. (2019). Tata Kelola Adminitrasi Keuangan, Dan Pembangunan Desa Tepi Laut Kabupaten Bengkulu Utara. Jurnal Pengabdian Masyarakat Bumi Raflesia, 2 (2).

Asmawi, M. (2017). The effect of compensation, empowerment, and job satisfaction on employee loyalty. International Journal of Scientific Research and Management, 5(12), 7590-7599.

Candra Dery Bagus, dkk. "Pengaruh Inovasi Produk Dan Brand Image Terhadapkep Keputusan Pembelian Pada Olivia Cake” Jurnal Aplikasi dan Bisnis. E-ISSN: 2407-5523, Hal. 86-91

Gifani Auliannisa, Syahputra. 2017. "Pengaruh Citra Merek Terhadap Keputusan Pembelian Produk Smartphone Oppo Pada Mahasiswa Universitas Telkom” Jurnal Bisnis dan Iptek. Vol.10 No.2, Hal. 82-92

Ghozali, Imam, 2011. "Aplikasi Analisis Multivariate Dengan Program SPSS”. Semarang: Badan Penerbit Universitas Diponegoro

Gumilang, Ratna Risa. 2019. "Implementasi Digital Marketing Terhadap Peningkatan Penjualan Home Industri” Jurnal Ilmiah Manajemen Vol.10 No.1, Hal. 10-11

Hanaysha, Jalal, Haim Hilman, Noor Hasmini Abdul-Ghani. 2014.” Efek Langsung dan Tidak Langsung dari Inovasi Produk dan Kualitas Produk pada Citra Merek: Bukti Empiris dari Industri Otomotif “ Jurnal Internasional Publikasi Ilmiah dan Penelitian. Manajemen Bisnis Vol.4. Edisi 11, Hal.2-5 
Indah, Rasyid, Tri. 2018. "Pengaruh Inovasi Produk Dan Harga Terhadap Keputusan Pembelian Sepeda Motor Dikota Tangerang Selatan” Jurnal Perspektif. Vol.16 No.1, Hal. 40-49

Marheni Eka Saputri, Tutut Ratna Pranata. 2014. "Pengaruh Brand Image Terhadap Ksetiaan Pengguna Smartphone Ipohone” Jurnal Fakultas Komunikasi dan Bisnis. Vol.13 No.3, Hal. 191-201

Nasir, Akhmad. 2018. "Pengaruh Inovasi Produk terhadap Kinerja Pemasaran Industri Mebel di Kabupaten Pasuruan". Penelitian ilmiah," Jurnal Ilmu Manajemen dan Akuntansi Vol.6 No.2, Hal. 18-20

Onsardi, O. (2018). Loyalitas Karyawan pada Universitas Swasta di Kota Bengkulu. COSTING: Journal of Economic, Bussines and Accounting, 2(1), $1-13$.

Onsardi, O. (2019). Pengaruh Kompensasi Dan Pemberdayaan, Terhadap Loyalitas Karyawan Dengan Variabel Intervening Kepuasan Kerja (No. jsypg). Center for Open Science.

Robins, Coulter. 2010. Manajemen. Jakarta Erlangga

Sedarmayanti. (2011). Metodologi Penelitian. Bandung : Munandar Maju.

Shaleh, Rifki,. 2017. "Pengaruh Inovasi Produk Gaya Hidup, Harga Terhadap Keputusan Pembelian Minyak Rambut Stalker Pomade Di Un Kediri" Jurnal Ekonomi Manajemen. Vol.1 No.1, Hal. 2-12

Sugiyono, (2012). Metode Penelitian Kuantitaf Kualitatif dan R\&D. Bandung : Alfabeta

Sugiyono, 2010. Metode Penelitian Pendekatan Kuantitatif, Kualitatif, dan R\&D.Bandung : Alfabeta

Suhaily, Lily dan Syarief Darmoyo. 2017. "Pengaruh Kualitas Produk, Harga Persepsi Dan Citra Merek Terhadap Keputusan Pembelian Diperoleh Kepercayaan Pelanggan (Studi Pada Produk Elektronik Merek Jepang)" Jurnal Fakultas Ekonomi dan Bisnis. Vol.21 No.22, Hal. 5

Tambunan, Elisabet dan Marupa Siregar. 2018. "Pengaruh Promosi Dan Inovasi Produk Terhadap Keputusan Pembelian Batik Azzahra Medan" Jurnal Mutiara Manajemen. Vol.3 No.1, Hal. 3-9

Wulandari, Dwi ajeng dan Farah Oktafani. 2017. "Pengaruh Brand Image Terhadap Proses Keputusan Pembelian Sepatu Nike Pada Mahasiswa Komunkikasi Dan Bisnis Telkom University Bandung” Jurnal Ekonomi dan Bisnis. Vol. No.1, Hal. 50-58 